\title{
Sedimentary response to climate and sea level changes during the past 400 ka from borehole PRAD1-2 (Adriatic margin)
}

\author{
Domenico Ridente ${ }^{1,2,{ }^{*}}$, Fabio Trincardi ${ }^{1},{\text { Andrea } \mathrm{Piva}^{1}, \text { Alessandra Asioli }^{3} \text {, Antonio Cattaneo }}^{4}$ \\ ${ }^{1}$ Istituto di Scienze Marine (ISMAR-CNR), via Gobetti 101, 40129 Bologna, Italy \\ ${ }^{2}$ Now at Istituto di Geologia Ambientale e Geoingegneria (IGAG-CNR), via Bolognola 7, 00138 Roma, Italy \\ ${ }^{3}$ IGG-CNR, via Giotto 1, 35100 Padova, Italy \\ ${ }^{4}$ Ifremer, GM-LS, BP 70, 29280 Plouzané, France \\ *: Corresponding author : Ridente D., tel +39 06 49914153, email address : domenico.ridente@cnr.it
}

\begin{abstract}
:
Borehole PRAD1-2 was drilled in 186 m water depth on the upper slope of the central Adriatic, in the frame of Profiles across Mediterranean Sedimentary Systems (PROMESS1) European Union-funded project. The borehole penetrated $71.2 \mathrm{~m}$ through a stratigraphic interval characterized by subparallel seismic reflections and uniform seismic units. According to an age-depth model based on several independent proxies (including foraminifera and nannoplankton stratigraphy, $\partial^{18} \mathrm{O}$ curves, and magnetostratigraphy) the cored interval records Marine Isotope Stages and Substages (MIS) from MIS1 to the top of MIS11, thus encompassing the past $\sim 370 \mathrm{ka}$. PRAD1-2 therefore represents an unprecedented continuous record through the last four glacial-interglacial cycles from a proximal continental margin setting where depositional sequences are typically composed of progradational units. These progradational units record dominantly interglacial intervals (MIS5, MIS7, and MIS9) and appear composed of thicker highstand deposits (HST) formed during interstadials and thinner forcedregression units (FSST) deposited during stadials above distinctive downward shift surfaces. The development of thicker highstand deposits with a distinctively thicker bottomset reflects enhanced shore-parallel advection any time sea level rise leads to the drowning of the Adriatic shelf, triggering the formation of dense water and vigorous cyclonic circulation. This advection mechanism persisted in each cycle throughout the early phases of the sea level fall but progressively decreased as sea level fall proceeded approaching the maximum lowstand position, when most of the shelf became exposed. Relative sea level falls punctuating interglacials within each 100-ka cycle were thus accompanied by a dearth in sediment flux on the outer shelf. The alternation of HST and FSST progradational wedges with markedly different thickness and downlap geometry of their bottomsets is the most evident stratigraphic signature, within each 100-ka depositional cycle, of the impact on the shelf of higherfrequency $(\sim 20 \mathrm{ka})$ sea level cycles and concomitant supply fluctuations.
\end{abstract}

Keywords: Quaternary; high-frequency climate cycles; depositional sequences; Adriatic Sea 


\section{Introduction}

Sedimentary bodies on continental margins have long been grouped in discrete stratigraphic units separated by key surfaces that are mainly of two types: (1) erosional surfaces, across which variable amounts of preexisting deposits are removed; (2) nondepositional surfaces, recording an interruption in sedimentation and/or an interval of drastically decreased rates of sediment accumulation [Vail et al., 1977]. The deposition and preservation of sedimentary bodies can be interpreted following this basic distinction and by taking into account their internal geometry, lateral variability, and vertical stacking pattern. This essentially geometric approach allows recognition of discrete strata packages and of their hierarchic organization into depositional sequences [Mitchum et al., 1977; Van Wagoner et al., 1988; Mitchum and Van Wagoner, 1991]. [3] Studying modern continental margins within and outside the Mediterranean, several authors have ascribed Quaternary depositional sequences to 100-ka eustatic fluctuations paced by orbital cyclicity [Piper and Aksu, 1992; Sydow and Roberts, 1994; Somoza et al., 1997; Berne' et al., 1998; Skene et al., 1998; Rodero et al., 1999; Trincardi and Correggiari, 2000; Chiocci, 2000]. In these cases, depositional sequences appear dominantly composed by progradational deposits interpreted to represent a continuum from sea level highstand to lowstand conditions [Trincardi and Field, 1991; Sydow and Roberts, 1994; Morton and Suter, 1996; Rabineau et al., 1998; Tesson et al., 2000; Berne' et al., 2002; Ridente and Trincardi, 2002]. Only in few cases, however, this widely accepted interpretation is supported by direct borehole control on the age of the sequences, on the timing of formation of the bounding surfaces, and on the nature of intervening downward shift surfaces within each sequence [Sydow and Roberts, 1994]. [4] By drilling the Adriatic continental margin, Profiles across Mediterranean Sedimentary Systems (PROMESS1) project aimed at defining the impact of eustatic cycles on the architecture of Quaternary depositional sequences on a margin affected also by significant supply fluctuations and changes in sediment redistribution along and across the shelf [Cattaneo et al., 2003; Steckler et al., 2007]. Indeed, sediment dispersal on the central Adriatic margin is significantly influenced by changes in oceanographic regime and paleogeographic rearrangements introduced by repeated drownings and exposures of the broad and semienclosed Adriatic shelf [Trincardi et al., 1994; Correggiari et al., 1996; Cattaneo and Trincardi, 1999]. Such changes impact the entire Adriatic region reaching the south Adriatic slope [Verdicchio et al., 2007; Ridente et al., 
1 2007) and forcing the growth of progradational clinoforms along a shore-parallel belt (Ridente and 2 Trincardi, 2005; Palinkas and Nittrouer, 2006; Cattaneo et al., 2007; Steckler et al., 2007).

In this paper we exploit the multi-proxy stratigraphy obtained from borehole PRAD1-2 (Piva et al., 2008a, this Volume) in order to: 1) establish a precise correlation between the slope deposits (where the PRAD1-2 borehole was drilled) and the continental shelf where depositional sequences reach their maximum thickness and display a progradational architecture; 2) test the hypothesis that the four uppermost depositional sequences on the Adriatic margin record the last four 100-kyr Quaternary eustatic cycles; 3) test if the variable clinoform geometry of progradational units composing each sequence (as defined on seismic profiles) can be related to shorter-term climate and sea level cycles that punctuate the main 100-kyr cycles (as defined in PRAD1-2 stratigraphy).

\section{Regional setting}

The Adriatic Sea is part of a foreland basin actively deformed since the early Cenozoic. The basin is fragmented by several tectonic lineaments north and south of Gargano Promontory (Ridente and Trincardi, 2006), the most uplifted foreland sector (Royden et al., 1987; Doglioni et al., 1994; Bertotti et al., 1999). North of Gargano Promontory, the Central Adriatic shelf is bordered by the NW-SE Gallignani-Pelagosa Ridge and dissected by the SW-NE Tremiti-Pianosa structural high (Fig. 1). South of Gargano Promontory, the Gondola Fault Zone is an extensive E-W to NW-SE deformational system (Ridente et al., 2008, and references therein).

Seismic and well-log data collected for hydrocarbon exploration evidence that the Western Adriatic Margin records the progressive fill of confined basins of tectonic origin (Ori et al., 1986). These basins record foredeep deposition during the growth of the Apennine chain along the western Adriatic margin (Ricci Lucchi, 1986). The oldest foredeep deposits are Oligocene to Pliocene in age and have been progressively deformed as the Apennine thrust-front migrated eastward. The deformation of the Miocene-Pliocene foredeep succession produced a series of piggy-back basins that were filled by late Pliocene to early Pleistocene deposits (Ori and Friend, 1984). Since the Middle Pleistocene, the depositional pattern along the Adriatic margin shifts from that of a tectonicallycontrolled foredeep successions to that of cyclical depositional sequences recording the impact of glacial-interglacial cycles (Trincardi and Correggiari, 2000; Ridente and Trincardi, 2002).

The progressive fill of the basin led the Adriatic to the modern epicontinental-sea configuration, with its most extensive shallow portion located north of the mid-Adriatic deep (MAD), where the maximum depth is only $260 \mathrm{~m}$ (Fig. 1). The MAD is a small remnant basin confined by the Po River lowstand prodelta, to the north, and by the NW-sloping flank of the tectonic highs located to the south (Gallignani Ridge and Tremiti High; Fig. 1). PRAD1-2 borehole is drilled south of the MAD (Fig. 2), where the slope is characterized by a continuous stratigraphic record through the last $\sim 370$ 
Borehole PRAD1-2 was drilled on the upper slope of the Central Adriatic through a stratigraphic interval evidencing sub-parallel or gently landward-wedging seismic reflections (Fig. 2). The drilled stratigraphic interval encompasses the distal correlatives of progradational units on the shelf that include: a) Late Pleistocene-Holocene transgressive (TST) and highstand (HST) units deposited during the last post-glacial interval; b) a progradational wedge deposited during the Last Glacial Maximum on the northern margin of the MAD, where it is up to $200 \mathrm{~m}$ thick; c) four depositional sequences (numbered 1 to 4 , top-down) that have a thickness distribution parallel to the shelf edge and pinch-out seaward along the western flank of the Gallignani Ridge (Figs. 2 and 3). Data from gravity cores penetrating the substratum on top of the anticline structure of the Gallignani Ridge indicate a Middle Pleistocene age (Dondi et al., 1982; Curzi et al., 1984; Pasini et al., 1993) and allow constrain the interval of deposition of the four overlying sequences to the last $\sim 500 \mathrm{kyr}$ (Trincardi and Correggiari, 2000).

The four sequences are mainly composed of fine-grained deposits organized in progradational units (up to $20 \mathrm{~m}$ thick) on the Adriatic shelf ("regressive sequences" of Ridente and Trincardi, 2002) and extend north and south of Gargano Promontory (Fig. 3). These sequences were interpreted to record a 100-kyr cyclicity based on downward extrapolation of stratigraphic information from the younger sequence (Trincardi and Correggiari, 2000). Seismic units composing individual sequences consist essentially of oblique-tangential clinoforms (e.g., Mitchum et al., 1977) that dip at low angles (typically fractions of a degree); locally, plane-parallel (aggradational) units occur at the base of each sequence, particularly in sequence 1 (Ridente and Trincardi, 2002). The clinoform units record progradation during highstand to lowstand and include forced-regression deposits of the falling stage (FSST; Hart and Long, 1996; Plint, 1996); the basal plane-parallel seismic units, when present, have limited seaward extent but reach typically as far as the landward pinch-out of the hosting sequence, and are therefore interpreted to record deposition during phases of sea level rise (TST; Fig.4). Atop each sequence, shelf-wide erosional unconformities truncate the clinoform units, reflecting subaerial erosion during sea level fall and lowstand, as well as transgressive reworking during sea level rises (e.g., Nummedal and Swift, 1987; Demarest and Kraft, 1987; Battacharya and Willis, 2001). On the slope, the ES unconformities are replaced by their distal correlative conformities; only ES4 (top of sequence 4) maintains an erosional character also on the upper slope and truncates low-angle progradational clinoforms at the site where PRAD1-2 was retrieved (Fig. 2).

On the western Adriatic shelf, the four regressive sequences stack vertically and, altogether, form a composite shelf-perched wedge locally up to $\sim 100 \mathrm{~m}$ thick (Trincardi and Correggiari, 2000; Fig. 2). In the MAD, the distal equivalent of the composite shelf-perched wedge is overlaid by the Po lowstand prodelta accumulated during the last glacial interval (Fig. 2). The lack of a correlative lowstand wedge on the shelf margin south of the MAD indicates that the Po River was the main 
1 sediment source during this interval, and suggests that sediment supplied by the Po was almost entirely

2 trapped in the MAD during each successive lowstand period, when the basin width was reduced and 3 much of the shelf exposed (Ridente and Trincardi, 2005; Steckler et al., 2007). This evolution is in marked contrast with the dominant shore-parallel dispersal of fine-grained sediment during the modern highstand interval, resulting in a linear, coast-parallel depocentre distribution of the Late Holocene HST (Cattaneo et al., 2003; 2007).

The comparable internal architecture of the four regressive sequences reflects similar changes during successive climate and sea level cycles. However, there are higher-frequency sea level oscillations superimposed on the prolonged sea level fall within each 100-kyr cycle that are normally difficult to identify in continental shelf settings. The results from PRAD1-2 stratigraphy provide means for defining this shorter-term cyclicity, by distinguishing the relative highstand and forcedregression units within the progradational succession composing the bulk of each sequence.

\section{Results}

\subsection{Stratigraphy of PRAD1-2 borehole}

Borehole PRAD1-2, drilled in $\sim 186 \mathrm{~m}$ water depth on the upper slope of the Central Adriatic (Figs. 1, 2), provided a continuous stratigraphic section of $71.2 \mathrm{~m}$ through the distal correlatives of the four Middle-Upper Pleistocene regressive sequences and Late Pleistocene-Holocene LST, TST and HST deposits (Fig. 2). PRAD1-2 penetrated 15 m below ES4 without reaching the base of sequence 4, particularly thick at this site (Fig. 3). The Late Pleistocene-Holocene units and the four underlying regressive sequences are characterized by relatively uniform, fine-grained lithology at PRAD1-2, although grain size analysis evidences a coarser-grained composition of the lower part of the borehole, with more frequent cm-thick silt and sand layers within sequence 4 (Fig. 5).

Changes in the assemblages of planktic and benthic foraminifers, $\mathrm{O}$ and $\mathrm{C}$ stable isotope records and paleomagnetic measurements document major sea level and paleoceanographic changes in PRAD1-2 stratigraphy (Fig. 6). The main eco-biostratigraphic results and isotope stratigraphy from PRAD1-2 (Piva et al., 2008a, this Volume) allow precise definition of Marine Isotope Stages/Substages (MIS). According to $\partial^{18} \mathrm{O}$ curves based on benthonic foraminifera (Bulimina marginata), PRAD1-2 records stages and sub-stages from MIS1 to the top of MIS11, the entire succession therefore encompassing the past $\sim 370 \mathrm{kyr}$ (Fig. 6). The identification of Sapropel-equivalent levels and the recognition of the Iceland Basin Excursion (IBE) geomagnetic inversion ( $188 \mathrm{kyr} \mathrm{BP})$ reinforce the isotope-based chronology of PRAD1-2 (Fig. 6 and Piva et al., 2008a, this Volume, for further details).

The combined evidence of stable isotope records and abundance of warm-water planktic 
1 transitions from glacial to interglacial conditions during the past four major glacial-interglacial cycles

2 (Fig. 6). These Terminations are characterized by abrupt shifts of the isotopic composition between $3+4.5$ and $-0.5 \%$ (Piva et al., 2008a, this Volume). Termination IV is characterized by a major shift in 4 the benthic isotope curve (Fig. 6) but appears more complicated because of the occurrence of an interval characterized by coarser material with reworked microfauna above the interpreted mid point in

6 the isotopic shift, between 55 and $58 \mathrm{~m}$ below the seafloor (Fig. 5). Piva et al. (2008b, this Volume)

7 document that the alkenone record parallels the rapid warming observed on the benthic isotope record, confirming that the significant shift can be ascribed to Termination IV. It is likely that this interval documents deposition in shallower waters compared to the subsequent Terminations. These results define the age of the four regressive sequences proving that these sequences record a 100-kyr cyclicity punctuated by shorter intervals of climate and sea level changes consistently with the succession of isotopic stages and sub-stages of the SPECMAP curves (e.g. Imbrie et al., 1984; 1993; Prell et al., 1986; Martinson et al., 1987; Shackleton et al., 1990; Raymo, 1997; Waelbroek et al., 2002).

Based on the shelf-slope continuity of seismic units and key stratigraphic surfaces, these results can be extended to the shelf where depositional sequences display their progradational architecture (Fig. 7).

\subsection{Calibration of shelf progradational units with the PRAD1-2 stratigraphy}

The slope deposits around site PRAD1-2 include two main alternating types of seismic units:

20 1) uniform and sub-parallel seismic-reflector packages correlating to progradational units on the shelf;

21 2) onlapping units formed by landward converging seismic-reflector packages that are confined to the 22 upper slope and pinch-out toward the shelf edge (Fig. 8). The calibration of seismic stratigraphy with 23 borehole stratigraphy indicates that the Terminations coincide with the top reflector of each onlapping unit (Fig. 8). According to PRAD1-2 stratigraphy, the onlapping unit immediately below Termination TI includes MIS4, MIS3 and MIS2 (Fig. 8). The base of this onlapping unit therefore corresponds to the base of MIS4. Similar onlapping seismic units, although significantly thinner, also occur below Terminations TII and TIII and correspond to MIS6 and MIS8, respectively (Fig. 8). The onlap surface at the base of MIS2, MIS6 and MIS8 units coincides with the distal correlative of ES1, ES2, and ES3, respectively. No onlapping unit is observed instead at the top of ES4, which is markedly erosional also on the slope, where it marks the transition from MIS9 to MIS10, at ca. $55 \mathrm{~m}$ core depth (Fig. 8).

The recognition of landward onlapping reflector packages is crucial in correlating the stratigraphy of PRAD1-2 upslope and across the shelf, thereby calibrating the succession of progradational units forming each sequence with the record of isotopic stages and sub-stages recognized in the borehole. These landward onlapping units record essentially glacial lowstand deposits, whereas progradational units composing each sequence on the shelf record short-term sea level and supply fluctuations during the interglacials of each 100-kyr cycle (Fig. 9). 
On the slope, stratigraphic units within sequence 1 that deposited during distinct isotopic stages and sub-stages range in thickness from less than a meter (e.g., MIS5.4 and MIS5.2) to several meters (e.g., MIS3; Fig. 8). Upslope, along seismic profile AMC-236 (Fig. 1), the stratigraphic record of individual stages and sub-stages gradually increases in thickness, passing landward into a distinct progradational unit (Fig. 10). An exception to this pattern is represented by deposits of MIS3 and MIS4, which do not show any significant increase in thickness upslope of PRAD1-2 but rather pinchout on the upper slope, as seen for the overlying deposits of MIS2. Interestingly, the shelf progradational units that deposited during the warmer sub-stages MIS5.5, MIS5.3 and MIS5.1 show thicker bottomsets, while the progradational units that thin more rapidly seaward correlate to the cold isotopic sub-stages MIS5.4 and MIS5.2 (Fig. 10). Progradational units ascribed to distinct isotopic sub-stages in seismic profile AMC-236 were then correlated regionally along the shelf toward the Po catchment (Fig. 11) and the Tremiti-Gargano structural high (Fig. 12).

In the shelf area north of PRAD1-2 (Fig. 11), the progradational unit corresponding to MIS5.4 shows a marked basal contact along a high-amplitude reflector (compare with Fig. 4). This peculiar reflector geometry and basal contact is interpreted as the stratigraphic equivalent, albeit in a more distal and overall muddy setting, of the sharp-based lithologic contact marking a downward shift of progradational units in forced-regression deposits (e.g., Plint, 1988; 1991; Posamentier et al., 1992). Deposits of MIS5.1 are truncated at their top while the overlying deposits (including MIS4, MIS3 and MIS2 units) remain confined to the upper slope and do not show evidence of erosion at their top (Fig. 11). The very thick MIS2 interval, compared to equivalent older lowstand units (e.g., MIS6, MIS8 and MIS10), likely reflects the increased influence of the Po delta, that reached its southernmost position during the last glacial lowstand (Trincardi et al., 1996). In the shelf area south of PRAD1-2, offshore the Tremiti Islands structural high, the most distal progradational unit on the outer shelf ranges from MIS4 to early MIS2 and is characterized by a sharp basal contact on the underlying deposits of MIS5.1 (Fig. 10).

The above results indicate that, during the last glacial cycle, relatively thin progradational units formed on the Central Adriatic shelf during the cold isotopic sub-stages (MIS5.4 and MIS5.2 in particular) and have sharper basal surfaces that likely record a base-level fall. These units are the FSSTs reflecting intervals of relative sea level fall. FSST progradational units are characterized also by reduced thickness of bottomset deposits compared to progradational units of the intervening warmer isotope sub-stages (like MIS5.5, 5.3, 5.1) that record intervals of relative highstand (HST).

33 The HST and FSST progradational units also differ in their downlap geometry: HST units show subhorizontal/tangential bottomsets, whereas FSST units are characterized by converging bottomset reflectors that result in a more abrupt downlap on the basal surface (Figs. 11, 12). 
Seismic-stratigraphic analysis shows that the internal architecture of sequences 2 and 3 resembles that of sequence 1 with the alternation of relatively high- and low-angle progradational clinoforms with bottomsets displaying variable thickness and downlap geometry (Figs. 11, 12). Sequence 3 is dominantly composed of higher-angle progradational clinoforms in the southern area, possibly reflecting tectonic growth near the Tremiti Islands (Fig. 11). Instead, sequence 4 is markedly different in depositional style on the shelf, evidencing a more intense erosion of shelf progradational units (Ridente and Trincardi, 2002).

Sequence 2. Compared to the overlying and underlying sequences, sequence 2 is confined further seaward and has a reduced thickness on the entire Central Adriatic shelf (Ridente and Trincardi, 2002). This observation is consistent with the evidence of a less pronounced eustatic high during MIS7 compared to MIS1, MIS5, MIS9 and MIS11 (Raymo, 1997; Lourens, 2004) and a more pronounced lowstand during MIS6 (Waelbroek et al., 2002). However, the recognition of syntectonic pinch-outs within deposits of sequence 2, both north and south of Gargano Promontory, suggests that the Adriatic region also underwent a phase of more intense tectonic deformation during this interval (Ridente and Trincardi, 2006). Regional and local uplift during this interval may thus represent an additional factor for the more seaward confinement of this sequence. Correlation of MIS7 from PRAD1-2 site to the southern shelf shows that this interval is represented by a succession of progradational wedges with repeated changes in the pattern of downlap geometry, basal contact and seismic facies, similarly to what can be observed in sequence 1 (Fig. 12). On this basis, we recognize MIS7.5, MIS7.3 and MIS7.1 as progradational units characterized by the most extensive and thicker bottomsets (Fig. 12).

Sequence 3. Progradational units composing sequence 3 in the vicinity of PRAD1-2 include repeated changes between HST and FFST (Fig. 11), but their distinction is more complicated south of this area because of the overall similar high-angle dip and basal contact of clinoforms that compose this sequence on the shelf (Fig. 12). This pattern may reflect the growth of local tectonic highs in this area, generating higher shelf gradients and an increase of locally-derived material through sub-aerial erosion or through enhanced ravinement erosion. Therefore, defining a distinctive pattern of HST and FSST progradational units within MIS9 (that composes the bulk of sequence 3) is less straightforward.

28 Sequence 4. Sequence 4 is characterized by shingled reflectors truncated at their top by surface ES4 even in the upper slope area where PRAD1-2 is located. Up-slope, surface ES4 maintains its erosional 30 character but the underlying deposits do not show a clinoform pattern similar to all the three sequences above. In this area, the reflectors below ES4 appear sub-horizontal while the thickness of sequence 4 decreases as the underlying substratum becomes shallower. One of the reflectors truncated by ES4 corresponds to a sharp (likely erosional) surface at ca. $58 \mathrm{~m}$ depth in PRAD1-2 (Fig. 5). This sharp surface is the base of coarser-grained sediment and likely indicates wave reworking in an inner-shelf to shoreface environment (Fig. 5). Indeed, the abundant benthic microfauna in the interval between 55 and $58 \mathrm{~m}$ indicates a very proximal, inner shelf assemblage, dominated by Ammonia perlucida,

37 Islandiella islandica, Elphidium articulatum and Nonion pauciloculum. Some of these species, in 
1 particular A. perlucida, presently inhabit the modern Adriatic muddy coastal zone (Jorissen 1988;

2 Morigi et al., 2005), variably influenced by fluvial runoff and characterized by water depths $<20 \mathrm{~m}$

3 (the mean water depth where A. perlucida is dominant is $<10 \mathrm{~m}$, according to Morigi et al., 2005).

4 This interpretation is consistent with the observation that sequence 4 is intensely, and locally even

5 completely, eroded landward of PRAD1-2, where no remnants of progradational units are found.

6 Because of this vigorous erosion of the shelf, the depocentre of sequence 4 is located on the slope

7 close to the MAD (Fig. 3; Ridente and Trincardi, 2002) and PRAD1-2 lithologic log documents a

8 coarser sediment composition (silt and sand; Fig. 5).

10 5. Discussion

\subsection{Composite 100/20-kyr climate cycles and HST/FSST progradational units on the Adriatic shelf}

Quaternary depositional sequences on several continental margins largely reflect climate and sea level changes paced by the $\sim 100$-kyr orbital cyclicity (Piper and Aksu, 1992; Sydow and Roberts, 1994; Somoza et al., 1997; Berné et al., 1998; Skene et al., 1998; Rodero et al., 1999). However, the precise chronology of the units composing these depositional sequences, and their correlation with sea level curves derived from $\delta^{18} \mathrm{O}$ records, remain problematic. In particular, higher frequency climate and sea level oscillations can be superimposed on this 100-kyr cyclicity during the Quaternary (Shackleton and Opdyke, 1973; Broecker, 1984; Ruddiman et al. 1986; Shackleton et al., 1990; Raymo, 1997). These higher-frequency oscillations proved more difficult to identify in continental margin records (e.g., Carter et al., 1991; 1998). This difficulty reflects, particularly in proximal environments, stochastic depositional events punctuating the stratigraphic record and making the identification of high-frequency signals particularly difficult (Einsele, 1993).

A most important outcome of PRAD1-2 is confirming that the 100-kyr glacio-eustatic cyclicity is the first order factor controlling the deposition of sequences on the Adriatic margin (as originally suggested by Trincardi and Correggiari, 2000). On the Adriatic shelf, the bulk of each 100kyr sequence includes a succession of dominantly fine-grained, progradational deposits. Extensive seismic stratigraphic correlation from PRAD1-2 indicates that the variations in downlap geometry and thickness of bottomsets characterizing shelf progradational units reflect the alternation of relative highstand and forced-regression units within each sequence (Figs. 10-12).

On the Adriatic shelf, we observe that the forced-regression units alternate with relative highstand units characterized by flat bottomsets of greater extent and thickness. Forced-regression units have a sharper basal surface than HST units; this abrupt contact is interpreted as the distal part of the regressive surface of marine erosion (sensu Nummedal et al., 1993). This difference in the geometry and thickness of bottomsets within HST and FSST units is the most evident stratigraphic signature of the higher-frequency ( $20 \mathrm{kyr}$ ) cyclicity within each 100-kyr depositional cycle. Although 
1 high-frequency highstands represent a short interval in the overall falling sea level trend, the preserved 2 portions of relative highstand units appear to contribute significantly to the total volume of each 3 sequence. A significant and abrupt sea level rise is associated to the onset of successive highfrequency HSTs (in sequence 1 this is the case of MIS5.3 and MIS5.1) but no deposit can be firmly ascribed to this phase because it is not detectable on seismic profiles. The only exception is represented by the plane-parallel seismic units locally preserved at the base of sequence 1, recording Termination TII (TST units in Figs. 4 and 11). Similarly, there is no practical criterion for separating the relative lowstand deposit formed at the end of each higher-frequency sea level fall. With these limitations, it is not possible to further subdivide each 100-kyr sequence into smaller-scale depositional sequences.

\subsection{Progradational dynamics during short-term climatic variability}

The evidence of progradational deposits composed of alternating high-frequency FSST and HST reflects short-term changes both in supply and sediment dispersal during each 100-kyr sea level cycle. In the Adriatic, previous work indicates that sediment dispersal is shore-parallel and directed to the south, resulting in the redistribution of fine-grained sediment from the Po and the Apenninic rivers over hundreds of km; this situation is typical of highstand intervals (Cattaneo et al., 2003; 2007). This advection mechanism likely persists during the early phases of the sea level fall, and significantly contributes to the accumulation of the low-angle progradational mud wedges composing each 100-kyr depositional sequence (Ridente and Trincardi, 2005). However, the effect of shore-parallel advection likely decreases as sea level fall proceeds approaching the maximum lowstand, when most of the shelf becomes exposed (Steckler et al., 2007). For this reason, the bulk of each sequence on the shelf consists of progradational units that deposited during major highstands of interglacials MIS9, MIS7 and MIS5 (Fig. 13). The interglacial unit of MIS3 is instead poorly developed (Figs. 10-12), indicating low sedimentation rates during this interval characterized by substantially lowered sea level (60 to 80 m below modern sea level according to Waelbroek et al., 2002). The reduced thickness of the MIS3 progradational unit may reflect a drop in accommodation on the shelf below a critical threshold as the result of a prolonged sea level fall since MIS5.5. Below this threshold, a significant portion of the shelf became exposed, hindering the shore-parallel sediment dispersal that characterized previous highstand intervals (i.e. MIS5.5, MIS5.3, and MIS5.1). These results imply that:

a) MIS5, MIS7, and MIS9 progradational units constitute the bulk of sequence 1, sequence 2 and sequence 3, respectively. These thick progradational units are fine-grained and grow through the construction of subaqueous clinoforms through lateral advection, as suggested for the modern HST (Cattaneo et al., 2003, 2007; Ridente and Trincardi, 2005);

b) Within MIS5, MIS7 and MIS9 a higher order cyclicity is recorded, although smaller-scale sequences are difficult to resolve. As an example, MIS5 includes two significant sea level falls (in the order of several tens of meters) corresponding to MIS5.4 and MIS5.2. These falls produced downward 
1 and seaward shifts of the shoreline but were accompanied by a drop in sediment supply, possibly in response to the reduction in basin width that hampered lateral advection;

c) shorter-term and lower magnitude sea level fluctuations punctuating the 100-kyr cycles are recorded by consistent changes in the clinoform geometry, resulting in the thicker/flatter bottomsets of HST units and in the reduced seaward extent and more abrupt basal contacts of the FSST units (e.g., the basal high-amplitude seismic reflector that mimics a sharp-based contact);

d) at the scale of each 100-kyr sequence, interstadials within higher frequency oscillations record increased sedimentation rates on the outer shelf resulting in overall thicker deposits compared to the intervening sea level falls. On other Quaternary margins, instead, shelf-margin progradation occurs at lowstands (Suter and Berryhill, 1985) and shelf progradational units are commonly ascribed to exceptional preservation of shoreline deposits during glacial maxima (Rabineau et al., 2006; Bassetti et al., 2006; Jouet et al., 2006). This finding is consistent with the Adriatic progradational units being more muddy and characterised by very low angles and less lobate shape of depocentres compared to more common coarser-grained shelf-margin wedges.

\section{$\underline{5.3 \text { Sequence stratigraphy implications }}$}

The Central Adriatic margin records three orders of cyclicity of relative sea level change: 1) a 100-kyr cyclicity resulting in the deposition of four regressive sequences capped by regional erosion surfaces (ES); 2) a higher-frequency (likely 10-20 thousands of years) resulting in the repeated alternation of HST and FSST deposits within each major depositional sequence; and 3) a long-term trend (several hundreds of thousands of years), likely induced by regional subsidence, leading to the aggradational stacking pattern of the four 100-kyr sequences and to their enhanced preservation compared to the area south of Gargano Promontory (Ridente and Trincardi, 2002).

The above results provide new relevant constraints to the applicability of sequencestratigraphy concepts to Quaternary continental margins. According to the classical model of sequence stratigraphy, sediment supply is assumed to be steady, whereas changes in accommodation space represent the main factor controlling sequence architecture. Moreover, deposition is assumed to shift progressively seaward of any particular point only after all the accommodation landward of that point has been exploited; therefore, sediment bypass and along-margin redistribution are rarely taken into account. In contrast to most of the basic sequence stratigraphy concepts, the depositional sequences in the Adriatic emphasize the importance of supply dynamics, during short-term sea level changes, in shaping sequences and margin architecture.

In the Adriatic, a combination of subsidence and paleogeographic setting result in an unexpected pattern where the bulk of progradational units is composed by interglacial deposits (i.e. MIS5, MIS7 and MIS9, respectively in sequence 1, 2 and 3). In addition, each interglacial progradation is indeed punctuated by higher-frequency fluctuations in sea level leading to alternating 
1 Quaternary margins, including the Rhone passive margin where the bulk of the stratigraphic record in each 100-kyr sequence consists of glacial low-stand deposits (Bassetti et al., 2008, this Volume).

These results may prove useful in seismic-stratigraphic interpretation of progradational deposits not only on modern continental margins but also of ancient, outcrop-scale records. Indeed, the Adriatic is an excellent modern analogue for settings characterised by lower amplitude (few tens of meters) base level fluctuations (typical of clastic successions from pre-Quaternary geological periods), high sediment supply and relatively low wave regime but with a vigorous advection and near shore sediment trapping by ocean currents.

\section{Conclusions}

Borehole PRAD1-2 on the upper slope of the Central Adriatic basin reached the top of MIS11, $\sim 370 \mathrm{kyr} \mathrm{BP}$, providing an unprecedented shallow marine record through the last four glacial cycles that can be consistently correlated with oceanic records (Piva et al., 2008a, this Volume). The stratigraphic results of PRAD1-2 allow define the stratigraphic architecture in terms of sediment routing and preservation potential of depositional sequences on the Adriatic margin. More in general, these results provide new insights in the understanding of the stratigraphy of Quaternary continental margins and shed light on the possible mechanisms of deposition in the case of muddy forcedregression deposits in ancient rock records.

In the Adriatic, in particular:

1) a stack of progradational sequences separated by regional erosional surfaces on the shelf records a 100-kyr cyclicity; this interpretation has been already proposed based on indirect evidence. Interestingly, PRAD1.2 results prove that, within each sequence, the bulk of progradational units deposited during interglacials (i.e. MIS5, MIS7 and MIS9, respectively in sequence 1, 2 and 3).

2) Seismic stratigraphic correlation from the borehole to the shelf indicates that sedimentation within each sequence includes mud wedges with thicker bottomsets, deposited during interstadial sub-stages, and mud wedges with thinner bottomsets and sharper basal surfaces, deposited during stadials; transgressive deposits, if present, are very thin at the borehole site and below seismic resolution on most of the shelf. On the southern flank of the MAD, lowstand deposits onlap and pinch-out landward on the upper slope or outer shelf.

3) The development of thicker bottomsets in HST deposits reflects enhanced shore-parallel advection during relatively short-lived highstands of sea level likely accompanied by increased sediment supply, as indicated by the clinoform geometry, the dominantly muddy facies and the high accumulation rates (see also discussions in Ridente and Trincardi, 2005 and Cattaneo et al., 2007). Shore-parallel advection is toward the southeast and onsets any time sea level highstands result in the significant 
1 water forms through winter cooling and promote a counterclockwise circulation pattern similar to the 2 one observed today (Piva et al., 2008c).

3 4) On the slope, the lowstand units within each successive glacial-interglacial cycle show a 4 significantly increasing thickness. In PRAD1-2, MIS2 deposits are twice as thick as the MIS6 and 5 MIS8 counterparts, reflecting increased sedimentation likely related to progressive infill of the North

6 Adriatic by the Po and Apennine rivers. Deposits accumulated during MIS10 show comparable 7 thickness to those recording MIS2 but reflect a more proximal, shallower environment. This shallow8 water environment is confirmed by the occurrence of repeated $\mathrm{cm}$-thick silt and sand layers within the 9 deposit encompassing MIS10. Some of these coarser-grained intervals record the shallowest 10 depositional environment encountered by PRAD1-2 based on benthic foraminifera (ca. -20 m water 11 depth).

12 5) The dominance of shallow water deposits within the oldest sequence (sequence 4), combined with 13 the seismic stratigraphic evidence of an erosional truncation at the top of this sequence, suggest a 14 progressive deepening during successive sea level cycles. This evidence is consistent with regional 15 subsidence in the Central Adriatic, confirming previous tectono-stratigraphic reconstructions based on 16 the stacking pattern and depocentre distribution of the four Middle-Upper Pleistocene sequences 17 (Trincardi and Correggiari, 2000; Ridente and Trincardi, 2002; 2006).

\section{Acknowledgements}

20 This work was supported by EC-PROMESS-1 Project (EVR1-CT-2002-40024). We are grateful to M. 21 Tesson and an anonymous reviewer for greatly improving the quality of our work with their comments 22 and suggestions. Guest Editor S. Berné and Editor L. Labeyrie are acknowledged for their support and useful comments as well. We wish to thank the Promess Cruise Party for their work on board and all the people involved in PROMESS-1 Project. This is ISMAR-Bologna (CNR) contribution 1594. 


\section{REFERENCES}

Asioli, A., (1996), High resolution foraminifera biostratigraphy in the central Adriatic basin during the last deglaciation: A contribution to the PALICLAS Project, in Palaeoenvironmental Analysis of Italian Crater Lake and Adriatic Sediments, Mem. Ist. Ital. Idrobiol., vol. 55, edited by F. Oldfield and P. Guilizzoni, pp. 197-218, Ist. Ital. di Idrobiol., Verbiana-Pallanza, Italy.

Bassetti, M.A., G. Jouet, F. Dufois, S. Berné, M. Rabineau, and M. Taviani (2006), Sand bodies at the shelf edge in the Gulf of Lions (Western Mediterranean): Deglacial history and modern Processes, Marine Geology, 234, 93-109.

Bassetti, M.A., S. Berné, G. Jouet, F. Dufois, M., Taviani, B. Dennielou, J.A. Flores, A. Gaillot, R. Gelfort, S. Lafuerza, and N. Sultan (2008), Facies and high-resolution stratigraphy of late Quaternary forced-regressive shorefaces from the Gulf of Lions (Western Mediterranean Sea), this Volume.

Bhattacharya, J. P., and B. J. Willis (2001), Lowstand deltas in the Frontier Formation, Powder River basin, Wyoming: implications for sequence stratigraphic models, Am. Assoc. Pet. Geol. Bull., 85 (2), 261-294.

Berné, S., G. Lericolais, T. Marsset, J. F. Bourillet, and M. De Bastist (1998), Erosional offshore sand ridges and lowstand shorefaces: examples from tide- and wave-dominated environments of France, J. Sed. Res., 68 (4), 540-555.

Berné, S., P. Vagner, F. Guichard, G. Lericolais, Z. Liu, P. Yin, A. Trentesaux, and H. I. Yi (2002), Pleistocene forced-regressions and tidal sand ridges in the East China Sea, Marine Geology, 188, 293-315.

Bertotti, G., E. Casolari, and V. Picotti (1999), The Gargano Promontory, a contractional belt in the Adriatic plate, Terranova, 11, 168-173.

Broecker, W.S. (1984), Terminations, in Milankovitch and Climate, edited by Berger, A.L., et al., Reidel Publ., Dordrecht, pp. 687-698.

Carter, R. M., S. T. Abbott, C. S. Fulthorpe, D. W. Haywick, and R. A. Henderson (1991), Application of global sea level and sequence-stratigraphic models in southern hemisphere Neogene strata from 
New Zealand, in Sedimentation, Tectonics and Eustasy, edited by D. I. M. McDonald, Int. Ass. Sed., Spec. Publ. 12, 41-65.

Carter, R. M., C. S. Fulthorpe, and T. R. Naish (1998), Sequence concepts at seismic and outcrop scale: the distinction of physical and conceptual stratigraphic surfaces, Sedimentary Geology, 122, 165-179.

Cattaneo, A., A. Correggiari, L. Langone, and F. Trincardi (2003), The late-Holocene Gargano subaqueous delta, Adriatic shelf: Sediment pathways and supply fluctuations, Marine Geology 193,

Cattaneo, A., F. Trincardi, A. Asioli, and A. Correggiari (2007), Clinoform formation in the Adriatic Sea: Energy-limited bottomset, Cont. Shelf Res., 27, 506-525.

Cattaneo, A., and F. Trincardi, F. (1999), The late-Quaternary transgressive record in the Adriatic

Chiocci, F. L. (2000), Depositional response to Quaternary fourth-order sea level fluctuations on the Latium margin (Tyrrhenian Sea, Italy), in Depositional Response to Forced Regression, edited by

Correggiari, A., M. Roveri, and F. Trincardi (1996), Late Pleistocene and Holocene evolution on the North Adriatic Sea, Il Quaternario - It. J. Quat. Sc., 9, 697-704.

Curzi, P., S. D'Onofrio, M. Roveri, and M. Taviani (1984), Core ADS 74-24: a window on the latest Quaternary history of the Adriatic Sea, Giornale di Geologia, 46 (2), 61-77.

Demarest, J. M., and J. C. Kraft (1987), Stratigraphic record of Quaternary sea levels: implications for more ancient strata, in Sea level fluctuation and coastal evolution, edited by D. Nummedal, O. H.

Doglioni, C., F. Mongelli, and P. Pieri (1994), The Puglia uplift (SE Italy): an anomaly in the foreland Pikey, and J. D. Howard, Soc. Ec. Pal. Min., Spec. Publ., 41, 223-239. of the Apennine subduction due to buckling of a thick continental lithosphere, Tectonics, 13, 1309- 
1 Dondi, L., F. Mostardini, and A. Rizzini (1982), Evoluzione sedimentaria e paleogeografica nella Pianura Padana, in Guida alla Geologia del Margine Appenninico-padano, Guide geologiche regionali, Soc. Geol. It., edited by G. Cremonini, and F. Ricci Lucchi, pp. 47-58, Bologna.

Einsele, G. (1993), Marine depositional events controlled by sediment supply and sea level changes, Geol. Rundsch., 82, 173-184.

Embry, A.F. (1993), Transgressive-regressive (T-R) sequence analysis of the Jurassic succession of

Helland-Hansen W., and J.G. Gjelberg (1994), Conceptual basis and variability in sequence stratigraphy: a different perspective. Sedimentary Geology, 92, 31-52.

Helland-Hansen, W., and O. J. Martinsen (1996). Shoreline trajectories and sequences: description of various depositional-dip scenarios, J. Sed. Res. 66B, 670-688.

Hunt, D., and M. E. Tucker (1992), Stranded parasequences and forced regressive wedge systems tract: deposition during base-level fall, Sedimentary Geology, 81, 1-9.

Hunt, D., and M. E. Tucker (1995), Stranded parasequences and forced regressive wedge systems tract: deposition during base-level fall - reply. Sedimentary Geology, 95, 147-160.

Imbrie, J., J. Hays, D. Martinson, A. McIntyre, A. Mix, J. Morley, N. Pisias, W. Prell, and N. J. Shackleton (1984), The orbital theory of Pleistocene climate: Support from a revised chronology of the marine $\partial^{18} \mathrm{O}$ record, in Milankovitch and Climate, Part 1, edited by A. Berger et al., pp. 269-

Imbrie, J., A. Berger, and N.J. Shackleton (1993), Global Changes in the Perspective of the Past, in A review of the role of orbital forcing in climate change, edited by Eddy, J.A., and H. Oeschger, John M. Taviani (2006), Shoreface migrations at the shelf edge and sea-level changes around the last glacial Maximum, Marine Geology, 234, 21-42. 
1 Jorissen, F. J. (1988), Benthic foraminifera from the Adriatic Sea, principles of phenotypic variation, Utrecht Micropaleontological Bullettin, 37, 174 pp.

Lourens, L. J. (2004), Revised tuning of Ocean Drilling Program Site 964 and KC01B (Mediterranean) and implications for the $\partial^{18} \mathrm{O}$, tephra, calcareous nannofossil, and geomagnetic reversal chronologies of the past 1.1 Myr, Paleoceanography, 19, doi: 10.1029/2003PA000997.

Martinson, D. G., N. G. Pisias, J. D. Hays, J. Imbrie, T. C. Moore, and N. J. Shackleton, (1987), Age

Mitchum, R. M., P. R. Vail, and S. III Thompson (1977), Seismic stratigraphy and global changes in sea-level, part 2: The depositional sequence as a basic unit for stratigraphic analysis, in Seismic Stratigraphy - Applications to Hydrocarbon Exploration, edited by C. E. Payton, Am. Assoc. Pet.

Morton, R.A., and J.R. Suter (1996), Sequence stratigraphy and composition of Late Quaternary shelfmargin deltas, northern Gulf of Mexico, Am. Assoc. Pet. Geol. Bull., 80, 505-530.

Nummedal, D., and D. J. P. Swift (1987), transgressive stratigraphy at sequence-bounding unconformities: some principles derived from Holocene and Cretraceous examples, in Sea level fluctuation and coastal evolution, edited by D. Nummedal, O. H. Pikey, and J. D. Howard, Soc. Ec.

Nummedal, D., G. W. Riley, and P. L. Templet (1993), High-resolution sequence-architecture: a chronostratigraphic model based on equilibrium profile studies, in Sequence stratigraphy and facies associations, edited by H. W. Posamentier et al., Int. Ass. Sed., Spec. Publ., 18, 55-68. 
1 Ori, G. G, and P. F. Friend (1984), Sedimentary basins formed and carried piggyback on active thrust sheets, Geology, 12, 475-478.

Ori, G. G., M. Roveri, and Vannoni, F. (1986), Plio-Pleistocene sedimentation in the ApenninicAdriatic foredeep (Central Adriatic Sea, Italy), in Foreland Basins, edited by P. Allen, and P. Homewood, Int. Ass. Sed., Spec. Publ. 8, 183-198.

Palinkas, C. M., and C. A. Nittrouer (2006), Clinoform sedimentation along the Apennine shelf, Adriatic Sea, Marine Geology, 234, 245-260.

Pasini, G., M. L. Colalongo, P. V. Curzi, and M. Taviani (1993), Analisi paleoecologica degli 14

Piper, D. J. W., and A. E. Aksu (1992), Architecture of stacked Quaternary deltas correlated with

Piva, A., A. Asioli, N. Andersen, J. O. Grimalt, R. R. Schneider, and F. Trincardi (2008b), Climatic cycles as expressed in sediments of the PROMESS1 borehole PRAD1-2, central Adriatic, for the last 370 ka: 2. Paleoenvironmental evolution, Geochem. Geophys. Geosyst., 9,

Piva, A., A. Asioli, F. Trincardi, R. R. Schneider, and L. Vigliotti (2008c), Late-Holocene climate variability in the Adriatic Sea (Central Mediterranean), The Holocene, 18(1), 153-167.

Plint, A. G. (1988), Sharp-based shoreface parasequences and "offshore bars" in the Cardium formation of Alberta; their relationship to relative changes in sea-level, in Sea-level Changes - An Integrated Approach, edited by C. K. Wilgus et al., Soc. Ec. Pal. Min., Spec. Publ., 42, 357-370.

Plint, A. G. (1991), High-frequency relative sea-level oscillations in the Upper Cretaceous shelf clastics of the Alberta foreland basin: possible evidence for glacio-eustatic control?, in 
Sedimentation, Tectonics and Eustasy, edited by D. I. M. Macdonald, Int. Ass. Sed., Spec. Publ., $12,409-428$.

Plint, A. G. (1996), Marine and non-marine systems tracts in fourth order sequences in the earlymiddle Cenomanian, Dunvegan Alloformation, north-eastern British Columbia, Canada, in Highresolution sequence stratigraphy: innovations and applications, edited by J.A. Howell, and J.F. Aitken, Geol. Soc. Lond, Spec. Publ., 104, 159-191.

Plint A.G., and D. Nummedal (2000), the falling stage systems tract: recognition and importance in sequence-stratigraphic analysis, in Depositional Response to Forced Regression, edited by D. Hunt, and R, Gawthorpe, Geol. Soc. Lond., Spec. Publ., 172, 1-17.

Posamentier, H. W., and G. P. Allen (1993), Variability of the sequence stratigraphic model: effects of local basin factors, Sedimentary Geology, 86, 91-109.

Prell, W., J. Imbrie, D. Martinson, J. Morley, N. Pisias, N. J. Shackleton, and H. Streeter (1986), Graphic Correlation of oxygen isotope records: Application to the late Quaternary, Paleoceanography, 1, 137-162.

Rabineau, M., S. Berné, E. Ledrezen, G. Lericolais, T. Marsset, and M. Rotunno (1998), 3D architecture of lowstand and transgressive Quaternary sand bodies on on the outer shelf of the Gulf of Lion, France, Marine and Petroleum Geology, 15, 439-452.

Rabineau, M., S. Berné, J. Olivet, D. Aslanian, F. Guillocheau, and P. Jodeph, (2006), Paleo sea levels recognised from direct observation of paleoshoreline during Glacial Maxima (for the last 500,000 yr), Earth Pl. Sc. Lett., 252, 119-137.

Raymo, M. E. (1997), The timing of major climate terminations, Paleoceanography, 12(4), 577-585.

Reynolds, D. J., M. S. Steckler, and B. J. Coakley, (1991), The role of the sediment load in sequence stratigraphy: the influence of flexural isostasy and compaction, Journ. Geophys. Res., 96(B4), 6931-6949.

Ricci Lucchi, F. (1986), The Oligocene to Recent foreland basins of the Northern Apennines, in Foreland Basins, edited by P. Allen, and P. Homewood, Int. Ass. Sed., Spec. Publ., 8, 105-139. 
1 Ridente, D., and F. Trincardi (2002), Eustatic and tectonic control on deposition and lateral variability of Quaternary regressive sequences in the Adriatic basin, Marine Geology, 184, 273-293.

Ridente, D., and F. Trincardi (2005), Pleistocene "muddy" forced-regression deposits on the Adriatic shelf: a comparison with prodelta deposits of the late Holocene highstand mud wedge, Marine Geology, 222-223, 213-233.

Ridente, D., and F. Trincardi, (2006), Active foreland deformation evidenced by shallow folds and faults affecting late Quaternary shelf-slope deposits (Adriatic Sea, Italy), Basin Research, 18 (2),

Ridente, D., F. Foglini, D. Minisini, F. Trincardi, and G. Verdicchio, (2007), Shelf-edge erosion, sediment failure and the Middle Pleistocene inception of Bari Canyon on the South-Western

Ridente, D., D. Di Bucci, U. Fracassi, F. Trincardi, and G. Valensise (2008), Middle Pleistocene to Holocene activity of the Gondola Fault Zone (Southern Adriatic Foreland): deformation of a shear 19

Rodero, J., L. Pallarès, and A. Maldonado (1999), Late Quaternary seismic facies of the Gulf of Cadiz Spanish margin: depositional processes influenced by sea-level change and tectonic controls,

Royden, L. E., E. Patacca, and P. Scandone (1987), Segmentation and configuration of subducted lithosphere in Italy: an important control on thrust-belt and foredeep-basin evolution, Geology, 15,

Ruddiman, W. F., A. McIntyre, and M. E. Raymo (1986), Matuyama 41,000-year cycles: North 30

Shackleton, N. J., and N. D. Opdyke (1973), Oxygen isotope and palaeomagnetic stratigraphy of equatorial Pacific core V28-238: oxygen isotope temperature and ice volumes on a 105 and 106 year scale, Quaternary Research, 3, 39-59. 
1 Shackleton, N. J., A. Berger, and W. R. Peltier (1990), An alternative astronomical calibration of the lowe Pleistocene timescale based on ODP Site 677, Trans. Roy. Soc. Edinburgh, Earth Sc., 81, 251-261.

4

Skene, K., D. Piper, A. Aksu, and J. P. M. Syvitski (1998), Evaluation of the global oxygen isotope curve as a proxy for quaternary sea-level by modeling of delta progradation, J. Sed. Res., 68 (6), 1077-1092.

Steckler, M. S., D. Ridente, and F. Trincardi (2007), Modeling of sequence geometry north of Gargano Peninsula by changing sediment pathways in the Adriatic Sea, Cont. Shelf Res., 27, 526-

Suter, J. R., and H. L. jr. Berryhill (1985), Late Quaternary shelf margin deltas, Northwest Gulf of

Sydow, J., and H. H. Roberts (1994), Stratigraphic framework of late Pleistocene shelf-edge delta, Northeast Gulf of Mexico, Am. Ass. Pet. Geol. Bull., 78 (8), 1276-1312.

Tesson, M., H. W. Posamentier, and B. Gensous, (2000), Stratigraphic organization of late Pleistocene deposits of the western part of the Golfe du Lion shelf (Languedoc shelf), western Mediterranean

Trincardi, F. and M. E. Field (1991), Geometry, lateral variability, and preservation of downlapped 29 Sea, using high-resolution seismic and core data, Am. Assoc. Pet. Geol. Bull., 84 (1), 119-150.

Trincardi, F., A. Cattaneo, A. Asioli, A. Correggiari and L. Langone (1996), Stratigraphy of the lateregressive shelf deposits: Eastern Tyrrhenian margin, Italy, J. Sed. Petr., 61, 75-90.

Trincardi, F., A. Correggiari, and M. Roveri (1994), Late Quaternary transgressive erosion and deposition in a modern epicontinental shelf: the Adriatic semienclosed basin, Geo-Marine Letters, $14,41-51$. Palaeoenvironmental Analysis of Italian Crater Lake and Adriatic Sediments, Mem. Ist. Ital. 
Idrobiol., vol. 55, edited by F. Oldfield and P. Guilizzoni, pp. 39-70, Ist. Ital. di Idrobiol., 2 Verbiana-Pallanza, Italy.

4 Trincardi, F. and A. Correggiari (2000), Quaternary forced-regression deposits in the Adriatic basin and the record of composite sea-level cycles, in Depositional Response to Forced Regression, edited by D. Hunt, and R, Gawthorpe, Geol. Soc. Lond., Spec. Publ., 172, 245-269.

Vail, P. R., R. M. Mitchum, R. G. Todd, J. M. Widmier, S. III Thompson, J. B. Sangree, J. N. Bubb,

Van Wagoner, J. C., H. W., Posamentier, R. M. Mitchum, P. R. Vail, J. F. Sarg, T. S. Loutit, and J. 14 Hardenbol (1988), in Sea-level Changes - An Integrated Approach, edited by C. K. Wilgus et al., Soc. Ec. Pal. Min., Spec. Publ., 42, 39-45.

Verdicchio, G., F. Trincardi, and A. Asioli (2007), Mediterranean bottom current deposits: an example from the Southwestern Adriatic Margin, in Economic and palaeoceanographic significance of contourite deposits, edited by A. R. Viana and M. Rebesco, Geol. Soc. Lond., Spec. Publ., 276, $199-224$.

Waelbroek, C., L., Labeyrie, E., Michel, J.C., Duplessy, J.F., McManus, K., Lambeck, E., Balbon, and M. Labracherie (2002), Sea-level and deep water temperature changes derived from benthic foraminifera isotopic records, Quatern. Sc. Rev., 21, 295-305. 
3 Fig. 1 - Bathymetry of the Central Adriatic Basin where PRAD1-2 borehole was drilled. The Mid

4 Adriatic deep (MAD) is a small basin confined between the shallow North Adriatic shelf (NAS) and regional fold systems reflecting foreland deformation since the early Cenozoic (e.g., the GallignaniPelagosa Ridge and the Tremiti-Pianosa High). South of Gargano Promontory, the Adriatic margin is dissected by several fault systems, the most relevant of which is the Gondola Fault zone (GFZ). Track lines refer to seismic profiles reported in Figs. 2, 4, 7 and 10-12.

Fig. 2 - Stratigraphy of the Central Adriatic basin schematically reconstructed in a cartoon along a NNW-SSE section (A-B in Fig. 1, modified from Trincardi and Correggiari, 2000) based on the interpretation of high-resolution multi-channel seismic profile RF95-2 (lower). Seismic stratigraphy at PRAD1-2 is also shown (upper right). Deposits cored in PRAD1-2 consist mainly of the distal parts of four depositional sequences (labelled seq1 to seq4, top down) that thicken on the shelf (where they are progradational) and thin in the MAD (where they are overlaid by lowstand deposits). ES1 to ES4 are erosional unconformities on the shelf and become conformable on the slope, with the exception of ES4 that truncates underlying deposits at PRAD1-2 site.

Fig. 3 - Location of borehole PRAD1-2 with reference to the thickness distribution of the four Middle-Upper Pleistocene depositional sequences around Gargano Promontory (modified from Ridente and Trincardi, 2002).

Fig. 4 - A) Anatomy of seismic units within sequence 1 displaying repeated changes of seismic reflector pattern from oblique-clinoform to plane-parallel geometry. B) The observed variability in seismic reflector pattern correlates with the position of each seismic unit within the encompassing sequence; elementary seismic units are thus interpreted as distinct systems tracts. C) Wheeler diagram based on chronostratigraphic data from conventional cores (e.g., Trincardi et al., 1996; Asioli, 1996; Trincardi and Correggiari, 2000), which led Ridente and Trincardi (2002; 2005) to a preliminary interpretation of the chronologic relationship between seismic units (i.e. systems tracts) and the global sea level curve. Location of YD2 seismic profile is reported in Fig. 1.

Fig. 5 - PRAD1-2 is characterised by an overall fine-grained lithology but with a more frequent coarser-grained component (silt and fine sand) in the lower part (particularly below ES4, top of sequence 4). Note the interval between 55 and $58 \mathrm{~m}$ characterized by thin silty/sandy layers and a thick sandy interval with reworked microfauna and an erosional base. 
2 Fig. 6 - Summary of the stratigraphy of PRAD1-2 borehole modified from Piva et al. (2008a, this 3 Volume). Terminations (TI-TIV) are marked against the $\partial^{18} \mathrm{O}$ isotope curve derived from benthic 4 foraminifer Bulimina marginata. According to this interpretation, the borehole reached the top of 5 MIS11 at $68 \mathrm{~m}$ below sea floor.

7 Fig. 7 - Linedrawing based on Chirp Sonar seismic profiles CSS-700 and AMC-197 evidencing the stratigraphic architecture of the Adriatic margin and the correlation of key stratigraphic surfaces and units through the area where PRAD1-2 was retrieved.

Fig. 8 - Seismic stratigraphy at PRAD1-2 and chronostratigraphic calibration based on ecobiostratigraphy, identification of Mediterranean Sapropel-equivalent beds (S1 to S10), magnetostratigraphy $(\mathrm{IBE}=$ Iceland Basin Excursion) and oxygen stable isotope stratigraphy (MIS1 to MIS11). The linedrawing summarizes the regional pattern of stratigraphic units upslope of the borehole, where landward onlapping reflector packages correspond to lowstand intervals (cold isotope stages) and units deposited during interglacial intervals correlate to the progradational units composing the regressive sequences on the shelf. On the slope, the distal correlative of shelf erosion surfaces ES1 to ES3 split into a sequence boundary and a transgressive surface, respectively at the base and top of the glacial lowstand onlapping units. ES4 remains erosional (bold red line) down to PRAD1-2 site and no onlapping unit is observed above it.

Fig. 9 - Schematic representation of the stratigraphic relationship between landward onlapping units on the upper slope and progradational units on the shelf. The former record glacial lowstand intervals within each 100-kyr cycle, whereas the latter record essentially interglacial intervals.

Fig. 10 - Chronostratigraphic calibration of depositional sequences on the shelf along AMC-236 seismic profile intersecting PRAD1-2 site (location in Fig. 1). The stratigraphic intervals representing isotope stages and sub-stages in PRAD1-2 thicken upslope and correspond to distinct progradational units on the shelf. Colour code for seismic units based on legend of Figure 8.

Fig. 11 - Chronostratigraphic calibration of depositional sequences and progradational units on the shelf area north of PRAD1-2 site (location in Fig. 1). The sharp basal contact at the base of MIS5.4 unit marks relative sea level fall during this interval. Note the abrupt pinch-out of MIS5.4 unit above the basal downlap surface. In contrast, MIS5.5 unit, recording the preceding highstand interval, shows significantly thicker bottomset deposits and overall tangential geometry above the basal surface. Below MIS5.5 unit, a possible TST unit is confined to the inner shelf. Also note that MIS4 and MIS3 
1 units pinch-out and are confined to the upper slope, where MIS2 is significantly thick and shows 2 combined aggradational and progradational geometry.

4 Fig. 12 - Chronostratigraphic calibration of depositional sequences across the shelf south of PRAD1-2 5 site (location in Fig. 1), where relative highstand and falling/lowstand units are distinguished by their 6 seismic facies, basal surface, bottomset geometry and thickness. Note the abrupt pinch-out and marked 7 downlap pattern of units deposited during the relative sea level fall/lowstand of cold stages. Instead, 8 progradational units recording relative highstands develop thick bottomset deposits that extend further 9 seaward maintaining a plane-parallel geometry. The most distal progradational unit on the outer shelf 10 likely includes early MIS2, MIS3 and MIS4 deposits and is characterized by a very sharp basal contact 11 on the underlying MIS5.1 unit.

14 Fig. 13 - Simplified depositional scheme showing the combined influence of sea level change and 15 sediment dispersal on the geometry of progradational clinoforms. A) Enhanced supply and vigorous 16 alongshore sediment dispersal lead to the development of thick plane-parallel/tangential bottomsets 17 during highstand intervals; this style reflects maximum basin width and oceanographic conditions 18 characterised by bottom-water formation and by a vigorous shore-parallel dispersal along the western 19 margin. B) During sea level fall, the effect of advection decreases compared to wave-base erosion 20 leading to sharp-base progradational clinoforms characterised by thin downlapping bottomsets. C) 21 These two scenarios alternate during each 100-kyr eustatic cycle, with an intensification of contrasting 22 effects (reduced advection, increasing erosion) when sea level approaches the maximum lowstand. 


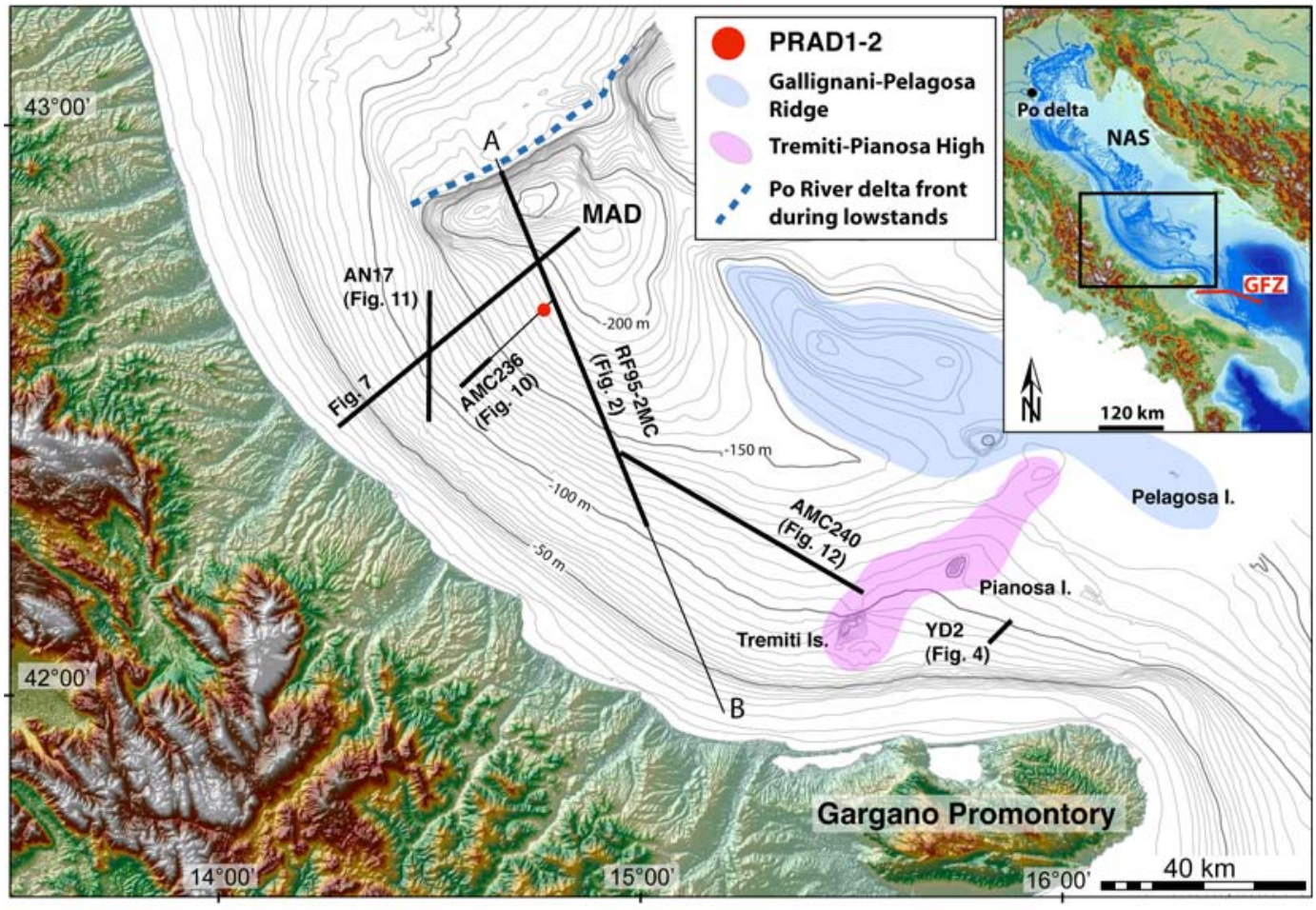

2

3 Fig. 1

4

5

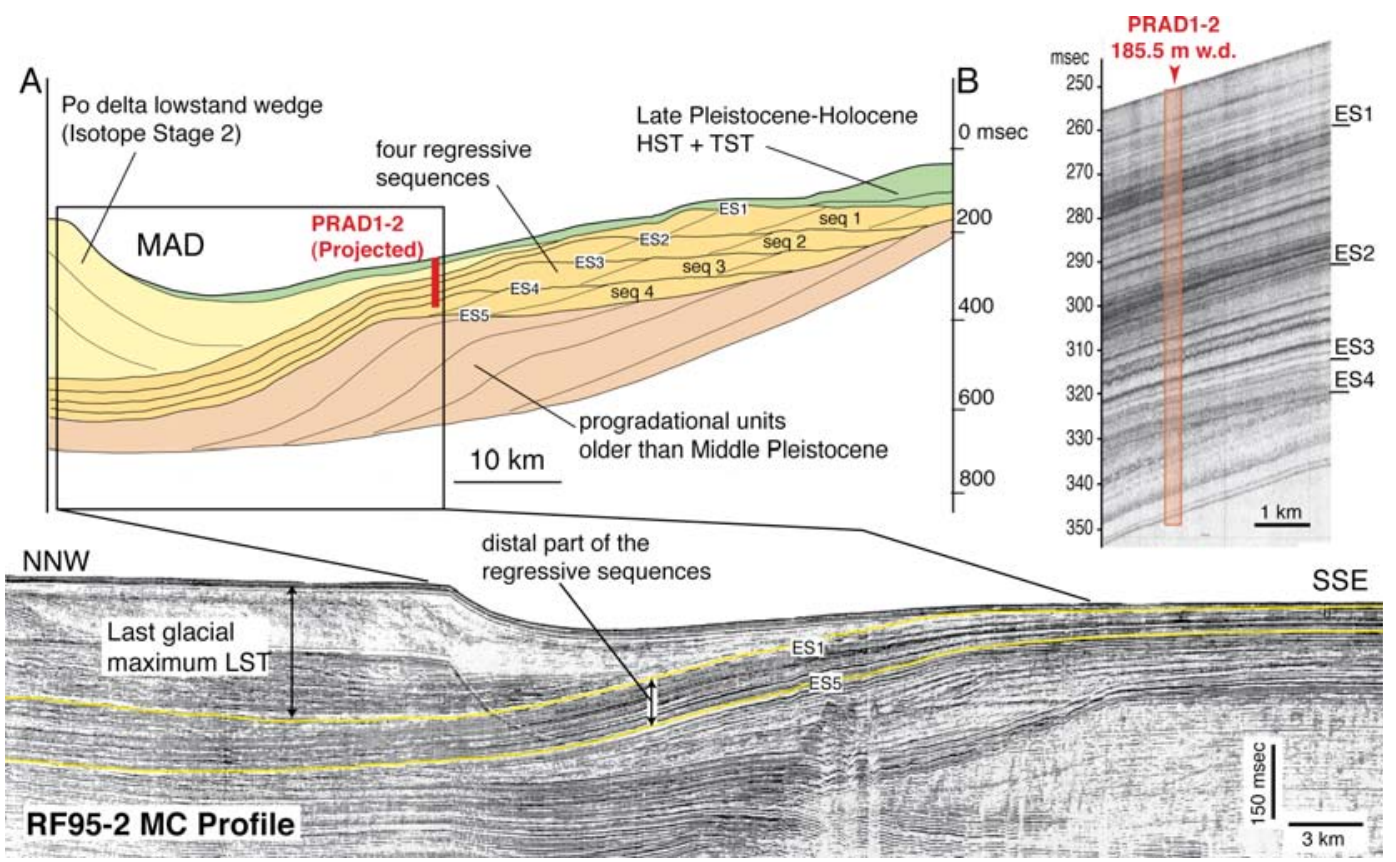

7 Fig. 2 


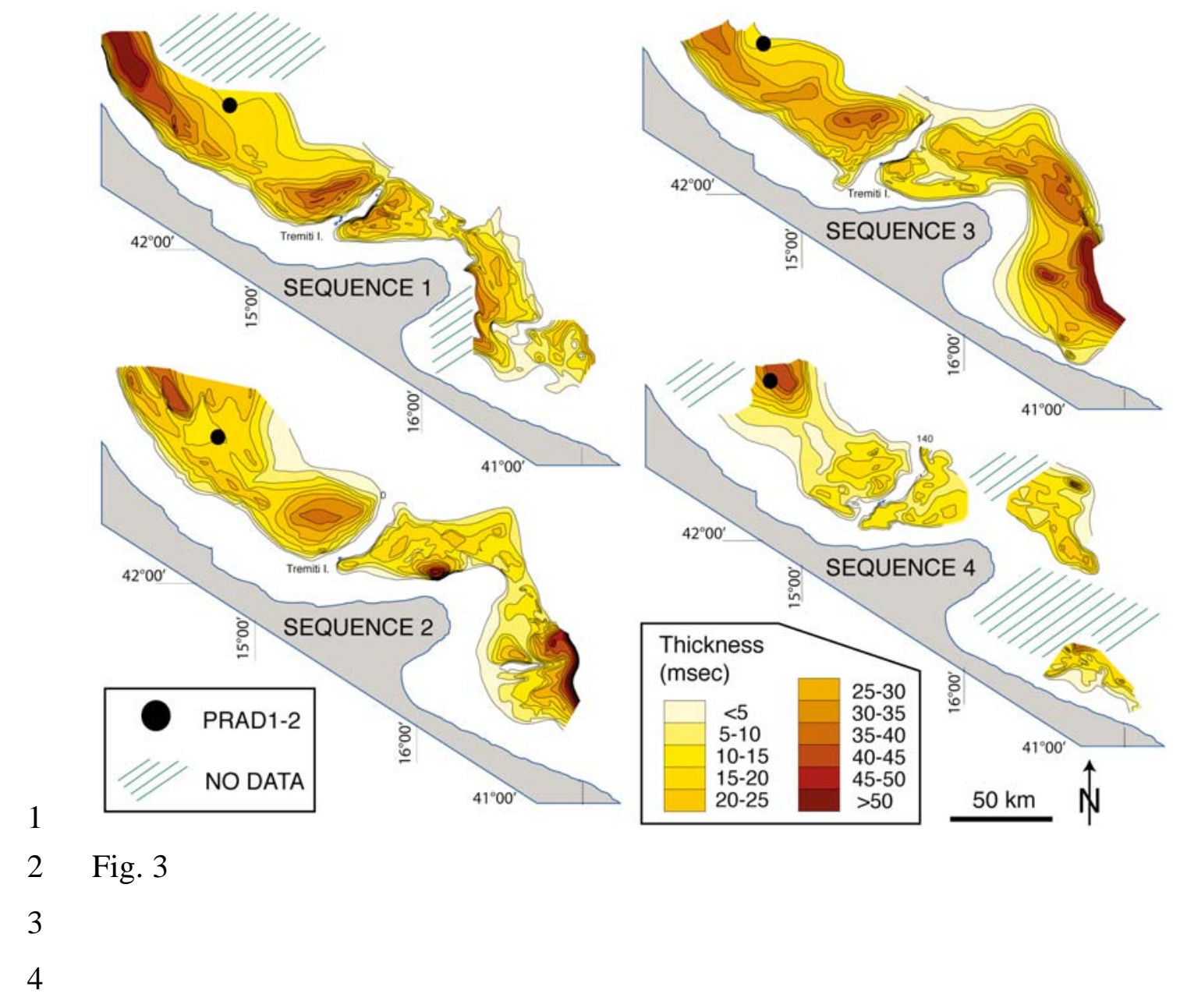



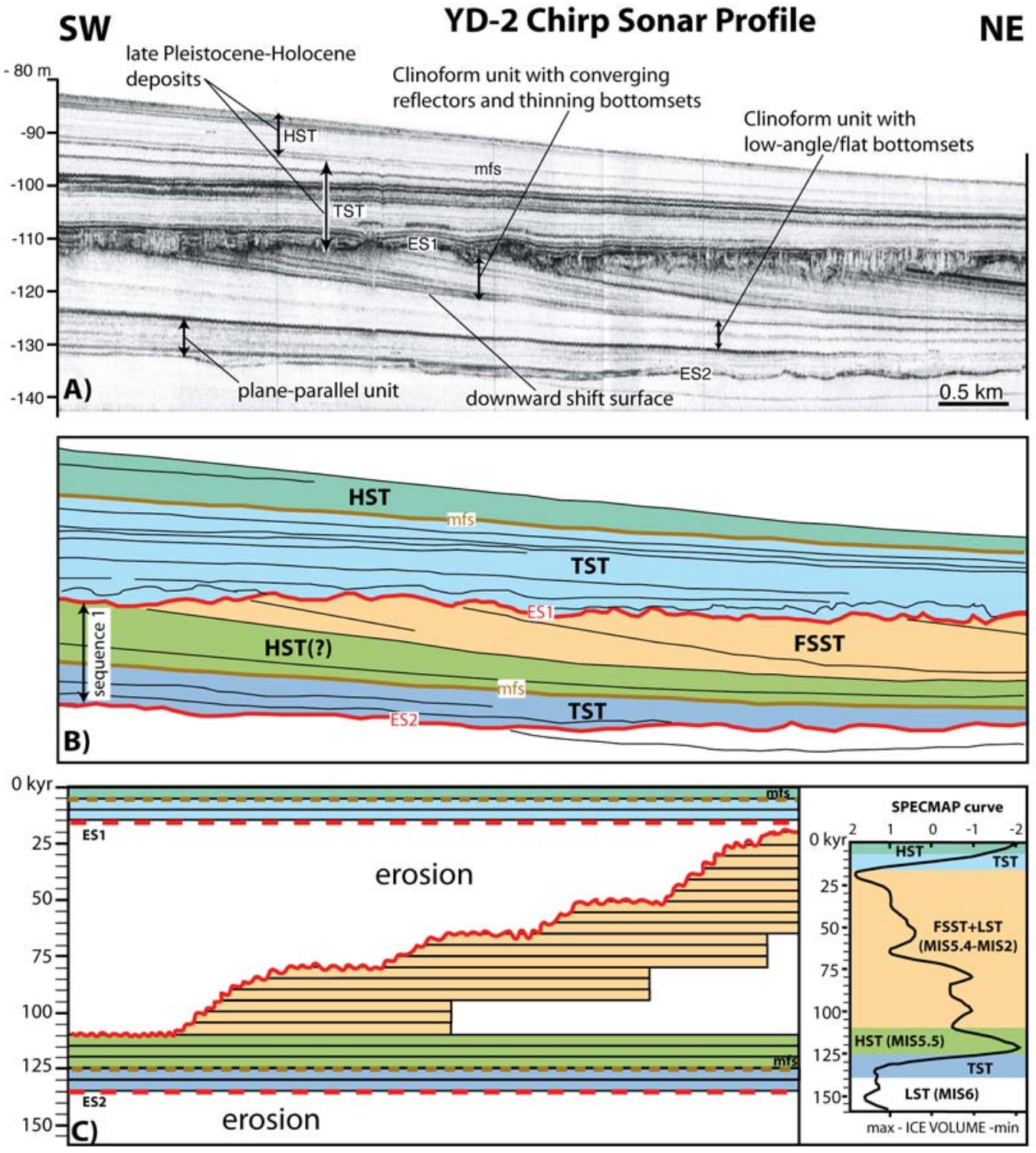

2 Fig. 4 


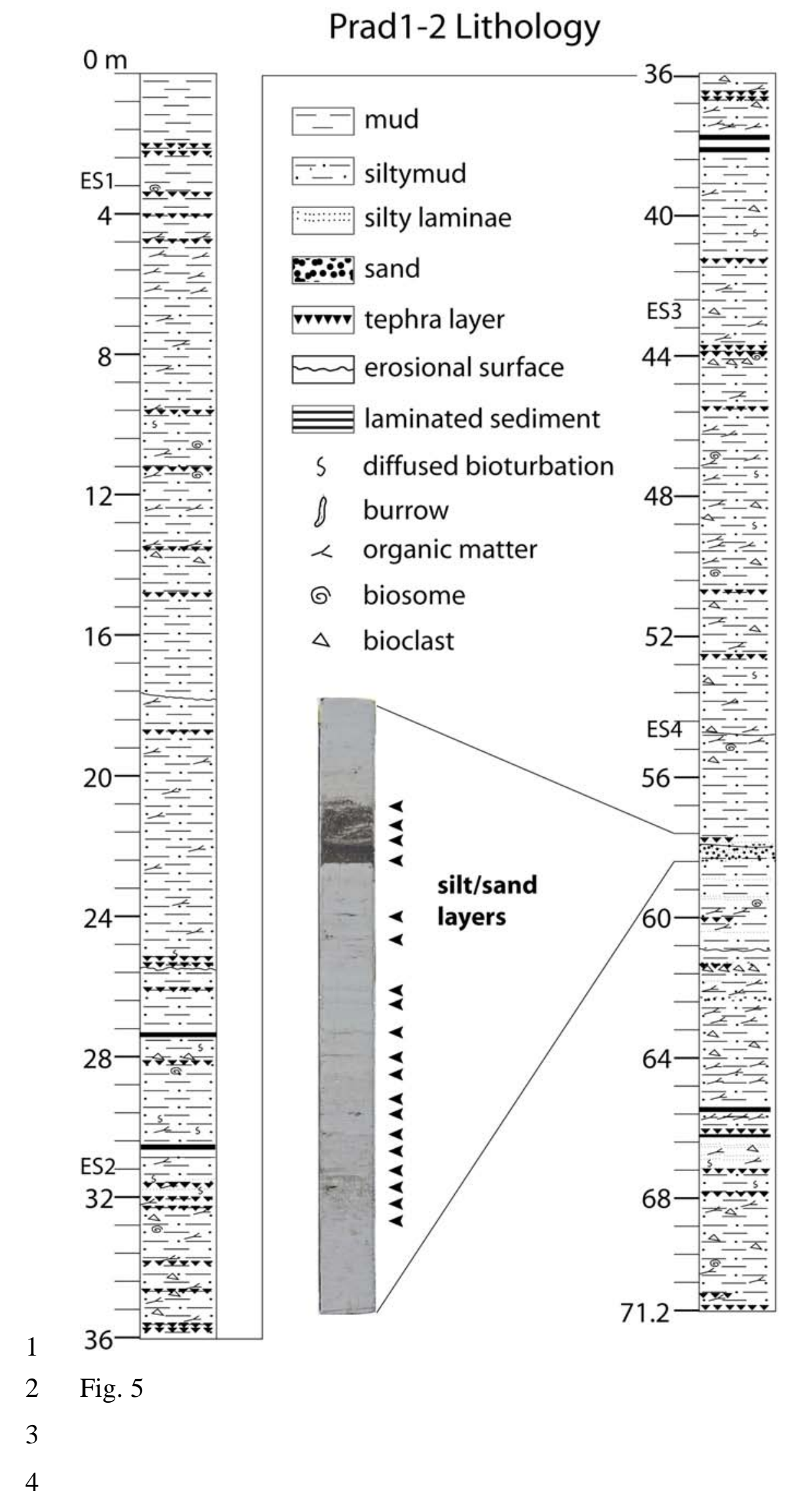


PRAD1-2 $\delta^{18} \mathrm{O}$ vs VPDB B. marginata Stratigraphy

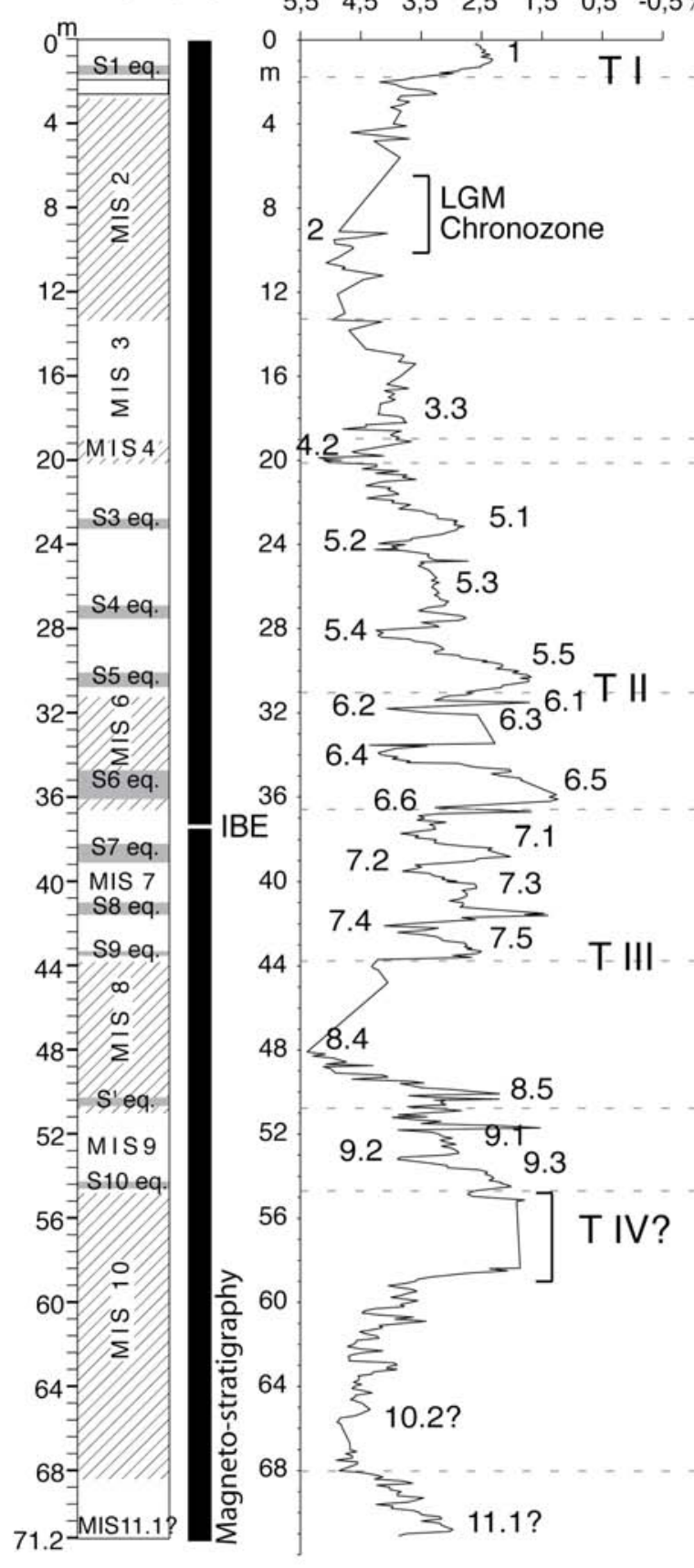

Elphidium+Ammonia warm planktic species

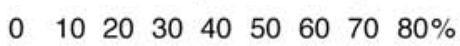

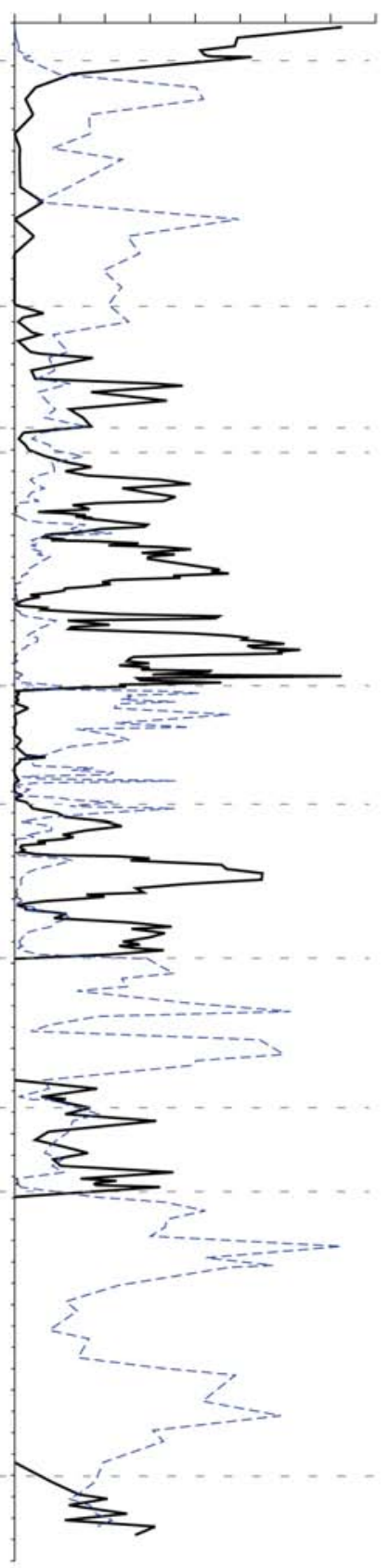

2 Fig.6 


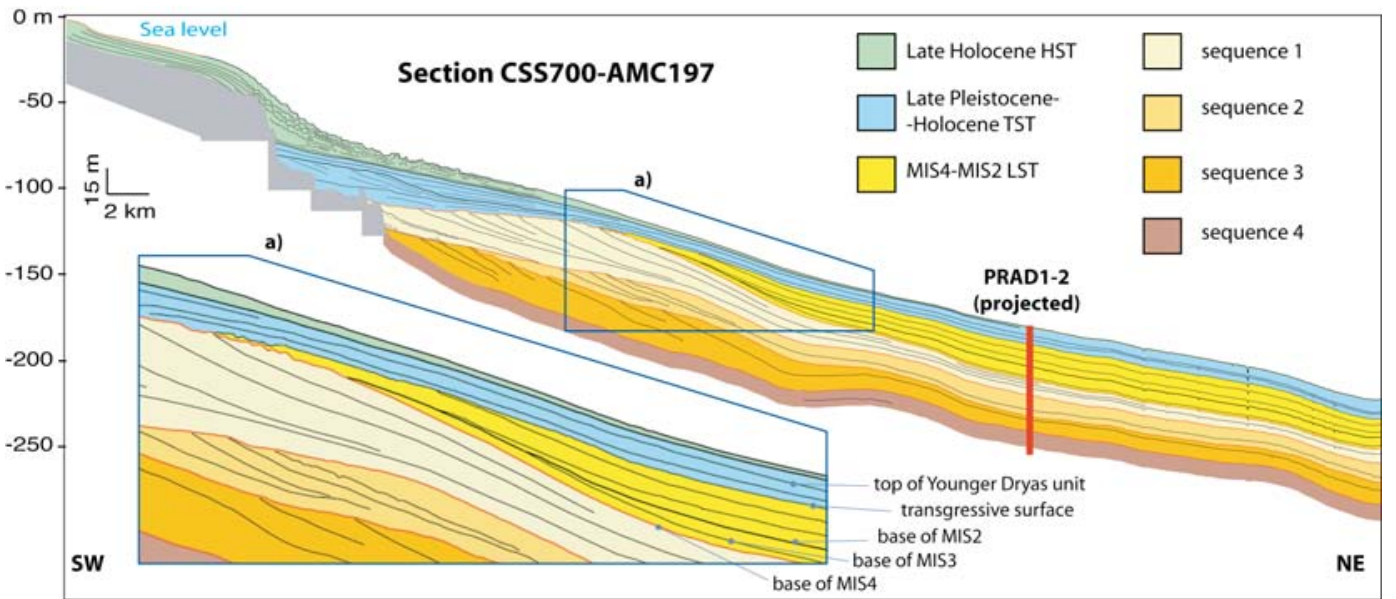

Fig. 7

3

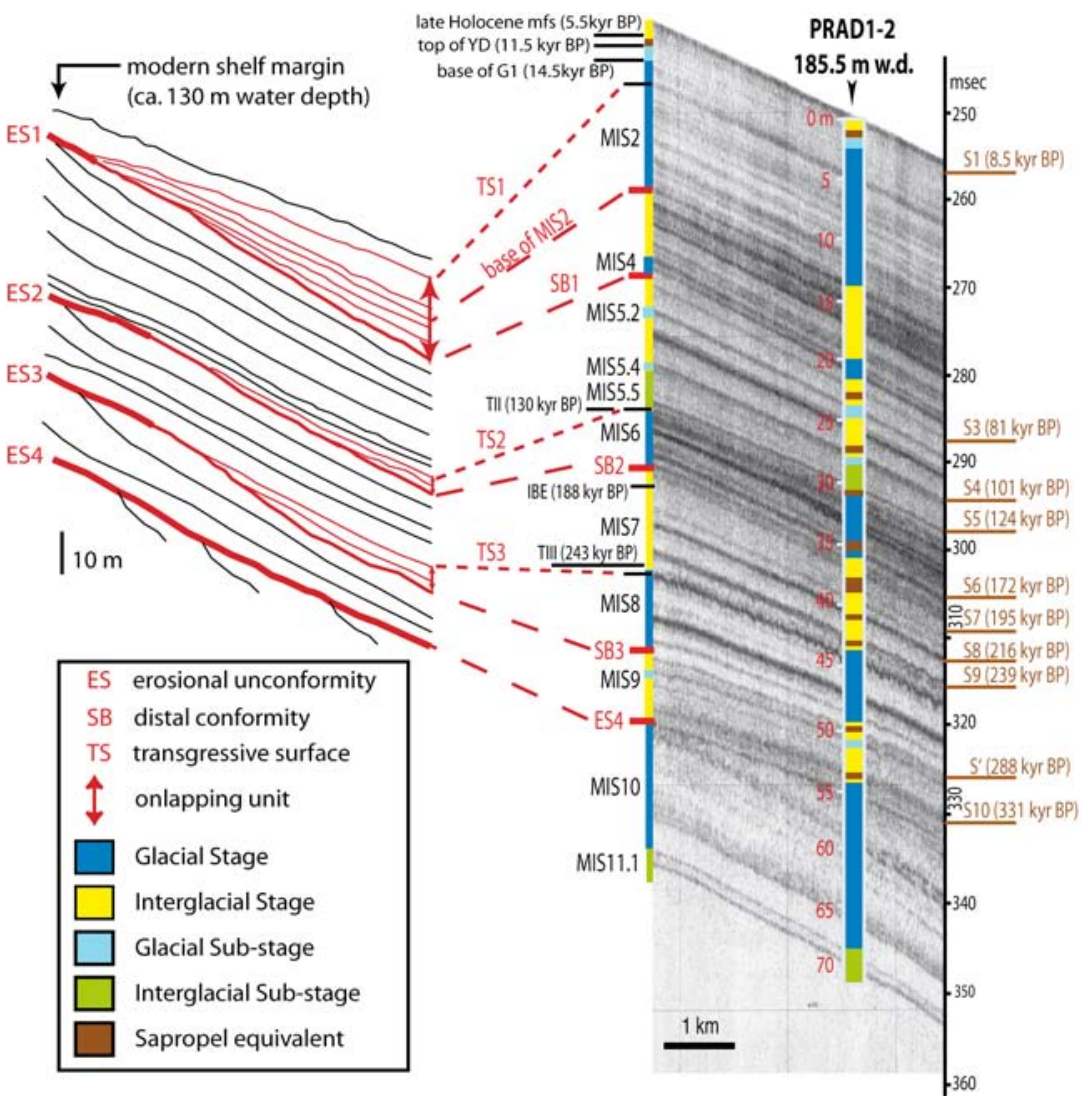

5 Fig. 8 


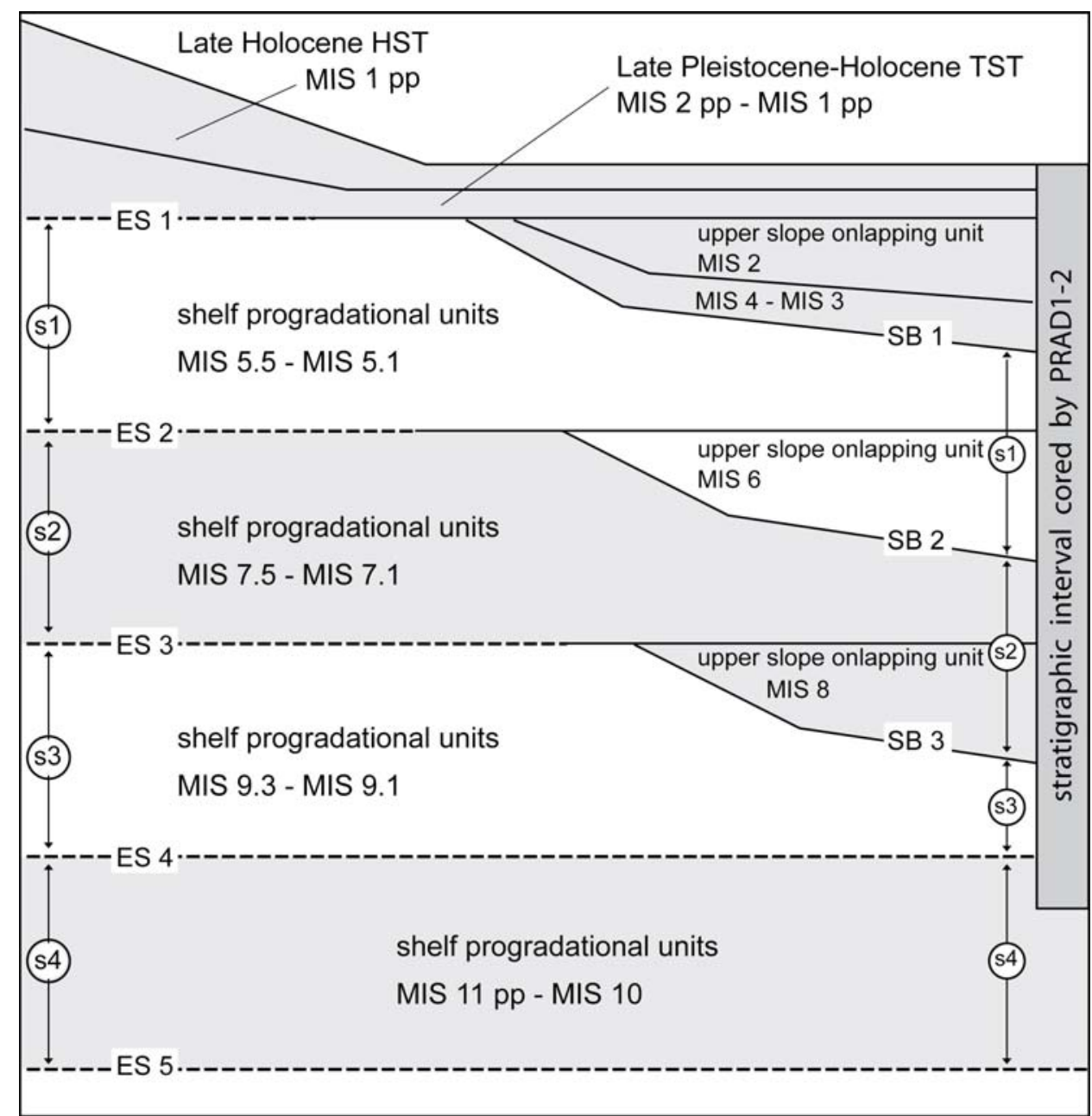

2 Fig. 9

3

SW

AMC-236 Chirp Sonar Profile

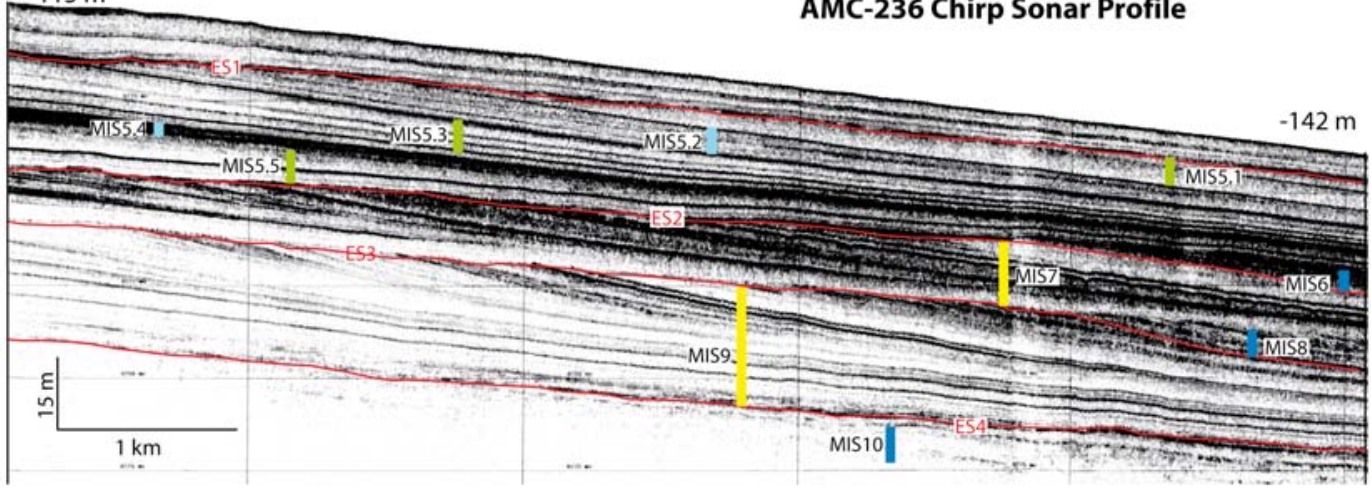

4

5 Fig. 10 


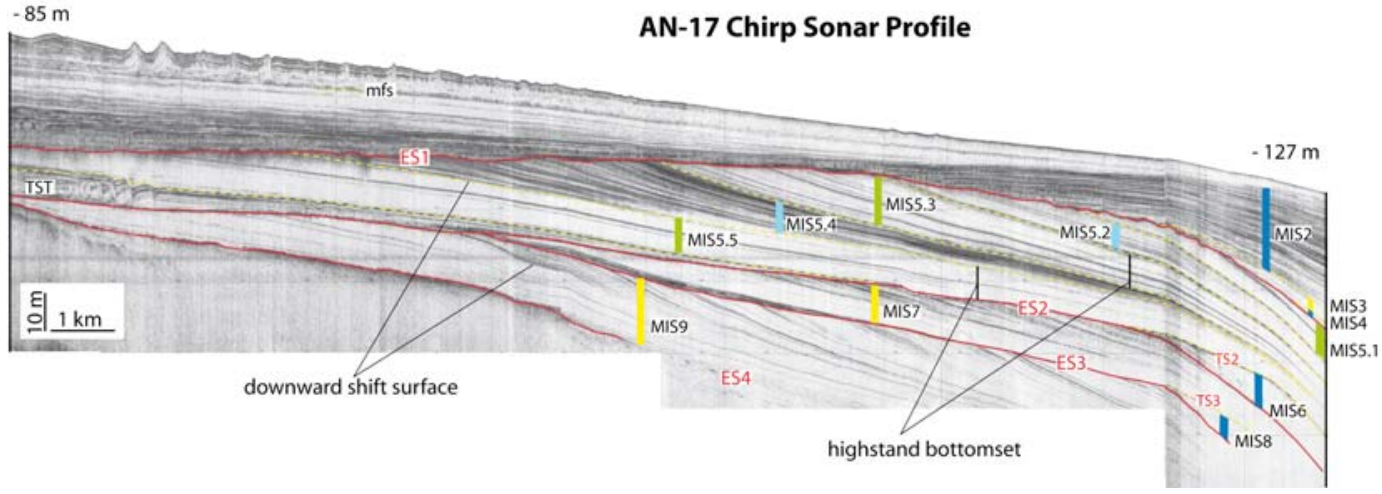

$2 \quad$ Fig. 11

3

4

5

6

7

8

NW

AMC-240 Chirp Sonar Profile

$-100 \mathrm{~m}$

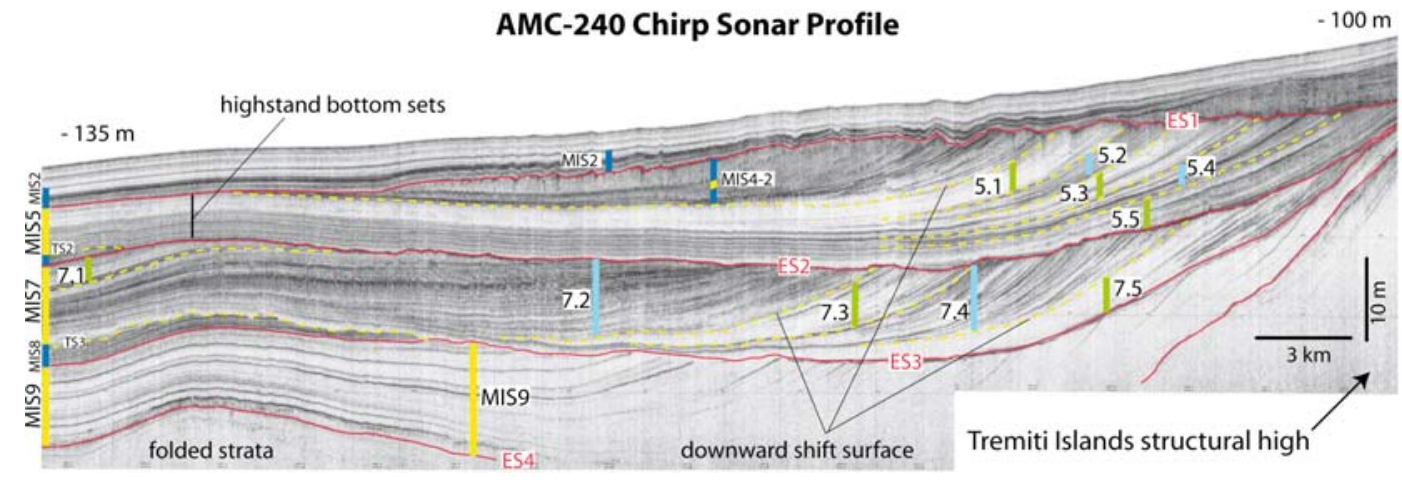

$10 \quad$ Fig. 12

11 
sealevel
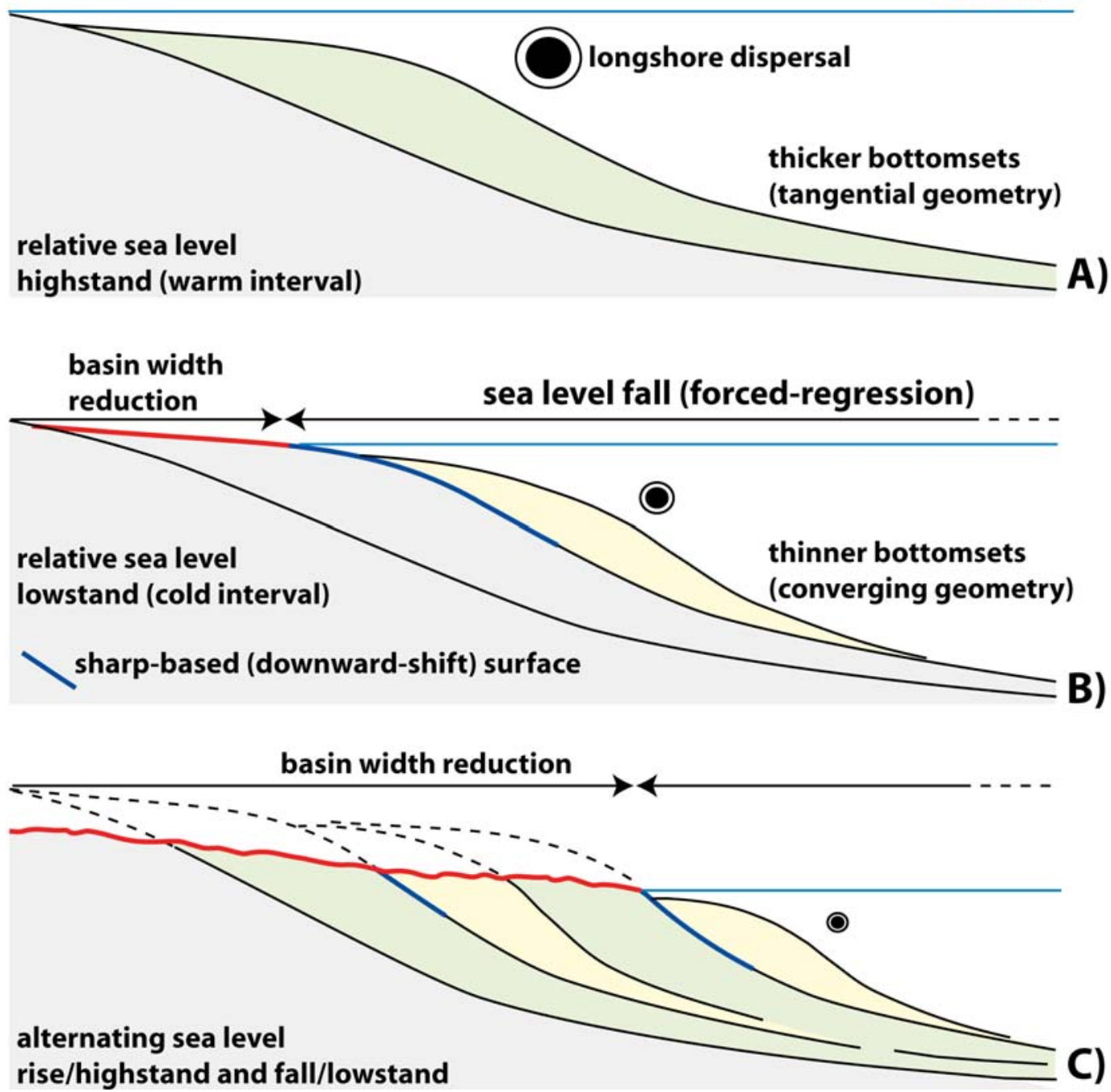

2 Fig. 13 